\title{
Disciplining Agricultural Support through Decoupling
}

\author{
JOHN BAFFES \\ THE WORLD BANK
}

HARRY DE GORTER

CORNELL UNIVERSIY

\author{
CORRESPONDENCE: John Baffes \\ The World Bank \\ 1818 H Street, NW \\ Washington, DC 20433, U.S.A. \\ tel. (202) 458-1880 \\ fax: (202) 522-3564 \\ email: jbaffes@worldbank.org
}

World Bank Policy Research Working Paper 3533, March 2005

The Policy Research Working Paper Series disseminates the findings of work in progress to encourage the exchange of ideas about development issues. An objective of the series is to get the findings out quickly, even if the presentations are less than fully polished. The papers carry the names of the authors and should be cited accordingly. The findings, interpretations, and conclusions expressed in this paper are entirely those of the authors. They do not necessarily represent the view of the World Bank, its Executive Directors, or the countries they represent. Policy Research Working

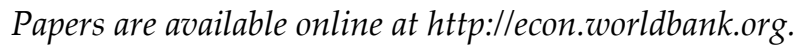

We would like to thank Ataman Aksoy, John Beghin, Gaston Gohou, Bernard Hoekman, John Nash, and Marcelo Olarreaga for helpful comments and suggestions on earlier drafts. The paper has benefited from discussions with Uri Dadush, Tassos Haniotis, Richard Newfarmer, and Nick Stern. Comments received from participants at the 2003 ABCDE-Europe Conference and seminars at the University of Georgia and the World Bank are greatly appreciated. An earlier (shorter) version of this paper appeared in Global Agricultural Trade and Developing Countries, edited by Ataman Aksoy and John Beghin (World Bank 2004). 


\section{CONTENTS}

\section{ACRONYMS AND ABBREVIATIONS}

SUMMARY

\section{INTRODUCTION}

II. NATURE AND TRENDS OF AgRicUltURAL SUPPORT

How High Is Agricultural Support?

Consequences of Agricultural Support

Objectives of Agricultural Support

Disciplining Agricultural Support

\section{Decoupling As A CONCEPT}

What Is Decoupling?

The Economics of Decoupling

Decoupling as a Subsidy Disbursing Mechanism

Decoupling and the Costs of Taxpayer Funds

The Micro-Side of Decoupling

\section{DeCoupling IN PRACTICE}

\section{Experience with Broad Decoupling Attempts}

Decoupling Efforts in the United States

Decoupling Efforts in the European Union

Decoupling Efforts in Mexico

Decoupling Efforts in Turkey

\section{Experience with Buyouts}

The 1984 New Zealand Exit Grant

The 1995 Canada Railway Subsidy ("Crow Rate") Buyout

The 2002 US Peanut Quota Buyout

The 2004 US Tobacco Quota Buyout

\section{Assessing Decoupling}

\section{ENDOTES}

\section{BOXES}

Box 1: $\quad$ The Political Rhetoric of Agricultural Support

Box 2: $\quad$ Early Decoupling Proposals in the United States and Europe

Box 3: $\quad$ The Minister's View of Decoupling

Box 4: $\quad$ Brazil vs. the United States

Box 5: $\quad$ Sectoral Initiative in Favor of Cotton

Box 6: The 1949 Brannan Plan in the United States and the 1968 Mansholt Plan in Europe

\section{TABLES}

Table 1: The Three Pillars of Agricultural Support under the URAA 
Table 2: $\quad$ The Road to (and from) Doha - WTO Ministerials

Table 3: Composition of Agricultural Support in OECD

Table 4: Agricultural Support in OECD, 1999-2001, average (US \$ billion)

Table 5: Characteristics of Agricultural Support in OECD, 1999-2001 average

Table 6: Decomposing Producer Support in OECD Countries

Table 7: PSE-Smaller and Large Impacts on Production and Trade

Table 8: Transfer Efficiency of Agricultural Support

Table 9: The Nature of the AMS, 1999 (US\$ million)

Table 10: Comparing the PSE and AMS, 1997-99

Table 11: The Distributional Impact of a Hypothetical Decoupled Support Program

Table 12: Chronology of Significant Decoupling and Recoupling Episodes

Table 13: Characteristics of four Decoupled Support Programs

Table 14: Composition of Agricultural Support in the US

Table 15: Composition of Agricultural Support in the EU

Table 16: Composition of Agricultural Support in Mexico

Table 17: Composition of Agricultural Support in Turkey

\section{FIGURES}

Figure 1: Measures of Domestic Support and OECD

Figure 2: Measures of Domestic Support and WTO

Figure 3: Production Subsidy of a Large Exporter

Figure 4: Import Tariff of a Large Importer

\section{REFERENCES}




\section{ACRONYMS AND ABBREVIATIONS}

$\begin{array}{ll}\text { ABARE } & \text { Australian Bureau of Agricultural and Resource Economics } \\ \text { AMS } & \text { Aggregate Measurement of Support } \\ \text { CAP } & \text { Common Agricultural Policy } \\ \text { CONASUPO } & \text { Compania Nacional de Subsistencias Populares } \\ \text { CSE } & \text { Consumer Support Estimate } \\ \text { DIS } & \text { Direct Income Support } \\ \text { EBA } & \text { Everything but Arms } \\ \text { ECSC } & \text { European Coal and Steel Community } \\ \text { EEC } & \text { European Economic Community } \\ \text { ERS } & \text { Economic Research Service } \\ \text { EURATOM } & \text { European Atomic Energy Community } \\ \text { FAIR } & \text { Federal Agricultural Improvement and Reform } \\ \text { GATT } & \text { General Agreement on Tariffs and Trade } \\ \text { GDP } & \text { Gross Domestic Product } \\ \text { GSSE } & \text { General Services Support Estimate } \\ \text { IF } & \text { Integrated Framework for Trade Related Technical Assistance } \\ \text { IFPRI } & \text { International Food Policy Research Institute } \\ \text { LDC } & \text { Least Developed Country } \\ \text { MERCOSUR } & \text { Mercado del Sur } \\ \text { NAFTA } & \text { North-America Free Trade Agreement } \\ \text { NGO } & \text { Non-Governmental Organization } \\ \text { OECD } & \text { Organization of Economic Cooperation and Development } \\ \text { PROCAMPO } & \text { Programa de Apoyos Directos al Campo } \\ \text { PSE } & \text { Producer Support Estimate (Production Subsidy Equivalent prior to 1991) } \\ \text { TSE } & \text { Total Support Estimate } \\ \text { URRA } & \text { Uruguay Round Agreement on Agriculture } \\ \text { USDA } & \text { United States Department of Agriculture } \\ \text { WTO } & \text { World Trade Organization } \\ & \end{array}$




\begin{abstract}
Agricultural protection and subsidies, particularly in high-income countries, have induced overproduction, thereby depressing world commodity prices and reducing export shares of countries which do not support agriculture. One-and perhaps the onlyeffective way to bring a socially acceptable and politically feasible reform is to replace payments linked to current production levels, input use, and prices by payments which are decoupled from these measures. This paper describes the objectives and consequences of agricultural support, surveys the theory and practice of decoupling agricultural support, and gives a number of policy recommendations on how to improve decoupled support mechanisms.

Overall, the experience with decoupling has been mixed while the switch to less distorting support has been uneven across commodities and countries. Ideally, compensation programs would be universal (open to all sectors in the economy, not just agriculture) or at least non-sector specific within agriculture. The paper describes a simple and minimally distorting scheme that would maintain government credibility and reduce uncertainty.
\end{abstract}




\section{EXECUTIVE SUMMARY}

Agricultural protection and subsidies, particularly in high-income countries, have induced overproduction, thereby depressing world commodity prices and reducing export shares of countries which do not support agriculture. Furthermore, not only is support costly, but it also goes to unintended beneficiaries-unintended as they relate to the stated objectives - thus exacerbating rather than eliminating the presumed income inequalities that justified its introduction in the first place. The stated objectives of such protection are numerous, but raising income to small farms appears to have been by far the most frequently used justification.

Given the harmful effects of such support on world markets along with the mismatch of stated objectives and ultimate outcomes, advocating outright elimination of support would be the natural way to proceed but this would reduce farm income in some instances and not be politically feasible. Thus, the relevant question is not the existence of support but what can be done with respect to the way it is given. One-and perhaps the only-effective way to bring a socially acceptable and politically feasible reform is to replace payments linked to current production levels, input use, and prices by payments which are decoupled from these measures.

The current WTO negotiations use the domestic support disciplines in the Uruguay Round's Agreement on Agriculture as a starting point and so it is important to understand how support is evolving and to assess the outcomes of decoupling efforts to date. This paper describes the objectives and consequences of agricultural support, surveys both the theory and practice of decoupling agricultural support, and gives a number of policy recommendations on how to improve decoupling support mechanisms.

Total direct support to agricultural producers as measured by the producer support estimate has remained fairly constant over time, averaging $\$ 248$ billion in 1999-2001 with most support concentrated in a few sectors (milk, meats, and rice). But the share of border support has declined from 77 percent in 1986-88 to 63 percent in 1999-2001 as taxpayer-financed subsidies paid directly to farmers have increased significantly. On the other hand, budget transfers to farmers rose 60 percent during this period, with large impact programs (i.e., output and input subsidies) increasing moderately compared with the substantial increases in so-called smaller impact programs (i.e., area payments, historical entitlements, and payments based on input use restrictions and overall farm income). However, several countries have made little progress in reforming the composition of support away from border support to domestic support (Japan, Korea), while others have not needed substantial reforms (many members of the CAIRNS Group).

The move from transfers with large impact on production and trade to transfers with a smaller impact on production and trade is often referred to as decoupling. However, decoupling has different meanings to economists, policymakers, and trade negotiators. Some see it as a transition mechanism to a fully competitive sector. Others see it as another support program, with less production- and trade-distorting effects. Some use 
decoupling only to refer to programs for transferring income to producers; others use it much more broadly, to include, for example, programs to improve the environment. Sometimes decoupling is assessed according to the policy's long-run impact on output through such factors as uncertainty, investment, and expectations.

Early agricultural policy reform attempts with decoupling elements failed (e.g. the 1949 Brannan plan in the United States and the 1972 Mansholt Plan in Europe). The first attempt toward decoupling was taken by the United States with the 1985 Farm Bill whereby support was based on historical rather than current yields. The European Union partially replaced intervention prices by decoupled payments following the Common Agricultural Policy reform of 1992. Mexico replaced price support with decoupled payments in 1994 with the introduction of PROCAMPO. The United States replaced deficiency payments with decoupled support in the 1996 farm bill. More recently Turkey replaced part of price support and input subsidies by decoupled payments. In addition to decoupled attempts there have been numerous one-time buyouts, including New Zealand's exit grant in 1984, Canada's grain transportation subsidy buyout, and more recently the buyout of the US peanut marketing quota under the 2002 Farm Bill.

Overall, the experience with decoupling agricultural support has been mixed while the switch to less distortive support has been uneven across commodities and countries. Rules have changed with new decoupling programs added so expectations about future policies affect current production decisions. Time limits were not implemented and if so, were overruled. Ideally, compensation programs would be universal (open to all sectors in the economy, not just agriculture) or at least non-sector specific within agriculture. A simple and minimally distorting scheme would be a one-time unconditional payment to everyone engaged in farming or deemed in need of compensation that is nontransferable, along the lines of one-time buyouts without remaining subsidies. To maintain government credibility and reduce uncertainty, eligibility rules need to be clearly defined and not allowed to change. The time period on which payments are based, the level of payments and the sectors covered should all remain fixed. Support to specific sectors within agriculture should be in the form of taxpayer-funded payments. There should be no requirement of production. Land, labor, and any other input should not have to be in "agricultural use." 


\section{INTRODUCTION}

For most of the past half-century industrial countries have had high levels of agricultural protection, provided by import tariffs, quantitative restrictions, and domestic support. Among the numerous claimed objectives of these policies, boosting the income of small family farms is by far the most frequently cited. Because most of this support is based on current output, input use, and prices, it induces overproduction. Given the weight of industrial countries in the global trading system, the aggregate effect of such support is to depress world commodity prices, hence reducing the export shares of countries that do not protect their agricultural sectors. Moreover, such support is costly for the subsidizing countries and often goes to unintended recipients, thus exacerbating rather than eliminating the presumed income inequalities that justified support in the first place.

Considering the harmful effects of such support on world markets and the mismatch between stated objectives and ultimate outcomes, its outright elimination has been often advocated. But societies have the right to transfer income to groups as they deem necessary. Thus, the relevant question is how support can be given without creating negative externalities for the rest of the world-how to increase farmers' incomes without distorting production and consumption. Perhaps the only effective way to achieve socially acceptable and politically feasible reform is to decouple payments from current production levels, input use, and prices.

Reforming agricultural support at a global level was first considered during the Uruguay Round (1986-94) of multilateral trade negotiations under the aegis of the General Agreement on Tariffs and Trade (GATT). ${ }^{1}$ Under the Uruguay Round Agreement on Agriculture (URAA) it was agreed that disciplines on agricultural protection would advance along the so-called pillars of agricultural support, namely market access, export subsidies, and domestic support. It was also agreed that all three types of protection would be subject to reduction commitments within a specific timetable (see table 1 for a summary of the three pillars of agricultural support).

Further disciplining agricultural support became part of WTO's mandate. The third WTO Ministerial meeting that took place in Seattle in November of 1999 was supposed to produce the basic framework and eventually launch what would have been the Seattle Round. However, the Ministerial ended in failure and hence no framework was adopted. Negotiations began again in early 2000 leading to the fourth WTO Ministerial in Doha in November of 2001. Following the meeting, the Doha Development Agenda was formally launched. The fifth Ministerial took place in Cancùn in September 2003, but ended in failure. Negotiations, however, continued and eventually led to a decision adopted by the WTO's General Council in August 2004 (see table 2).

In view of the complex nature of agricultural support as well as the difficulties faced by policy makers to reduce it (or even change its nature), this paper will address the following three issues: First, it will describe the objectives and consequences of agricultural support, including its measures by the OECD and WTO; second, it will survey 
both the theory and practice of decoupling agricultural support; and third, it will give a number of policy recommendations on how to improve decoupling support mechanisms. The paper proceeds as follows. The next section discusses the nature and trends of agricultural support, including its objectives, consequences, how high it has been and the disciplines imposed by the Uruguay Agreement on Agriculture. The third section looks at the concept of decoupling, especially its various definitions as well as the basic economic principle behind moving from domestic or border protection to decoupled support. Section IV looks at decoupling in practice. The first part of the section reviews the decoupling attempts by the United States, staring with the 1985 farm bill, the 1996 farm bill, and policy reversals with the introduction of the emergency payments in 1998 and their legitimization with the 2002 farm bill. The section also looks at the European Union, beginning with the 1992 CAP reform, followed by Agenda 2000 and the more recent decoupling attempts of the so-called Mediterranean products. The second part of the section examines four cases of buyouts, namely the 2002 US peanut quota buyout, the 1984 New Zealand exit grant, Canada's 1995 buyout of the railway subsidy for grain shippers, and the recent US tobacco buyout. The last section evaluates the effectiveness of these decoupling programs and derives a number of policy conclusions. 


\section{NATURE AND TRENDS OF AGRICULTURAL SUPPORT}

\section{How High Is Agricultural Support?}

The OECD annually monitors and evaluates direct and indirect transfers to (and from) agriculture of its member countries since 1986. Its measure of total support, the Total Support Estimate (TSE), consists of Producer Support (PSE), General Services Support (GSSE), and Transfers to Consumers (CSE) - table 3 summarizes the composition of agricultural support in OECD countries while figure 1 gives a diagrammatic illustration of the OECD measures of support. ${ }^{2}$

The PSE is defined as:

The annual monetary value of gross transfers from consumers and taxpayers to support agricultural producers, measured at farm gate level, arising from policy measures, regardless of their nature, objectives or impacts on farm production or income. ... The PSE is a gross notion implying that any costs associated with those policies and incurred by individual producers are not deducted. It is also a nominal assistance notion implying that increased costs associated with import duties on inputs are not deducted.

In others words, PSE is the additional money producers receive in a particular year because of government interventions in agricultural markets.

The PSE consists of two components. The first component, the market price support, is derived from border protection and it is defined as:" value of gross transfers from consumers and taxpayers (e.g., export subsidies) to agricultural producers arising from policy measures that create a gap between domestic and market prices of a specific agricultural commodity, measured at the farm gate level." The second component is taxpayer financed and includes direct payments to producers based on output, area planted or animal numbers, historical entitlements, input use, input constraints, or overall farm income. Note that export subsidies are both transfers from taxpayers and consumers but are in the border measure category.

The General Services Support Estimate is defined as:

An indicator of the annual monetary value of gross domestic transfers to services provided collectively to agriculture and arising from policy measures which support agriculture, regardless of their nature, objectives and impacts on farm production, income, or consumption of farm products. It includes taxpayer transfers to: improve agricultural production (research and development); agricultural training and education (agricultural schools); improving off-farm collective infrastructures, including downstream and upstream industry (infrastructures); assist marketing and promotion; meeting the costs of depreciation and disposal of public storage of agricultural products (public stockholding); and other general services that cannot be disaggregated and allocated to the above categories due, for example, to a lack of information.

The total support estimate to all OECD countries averaged $\$ 330$ billion annually during 1999-2001, with the European Union, United States, and Japan accounting for 29, 34 , and 20 percent, respectively (table 4 ). Of the $\$ 330$ billion of total support, consumers' 
burden was $\$ 183$ billion while the taxpayers' burden was $\$ 171$ billion. This adds to $\$ 354$ billion, of which $\$ 24$ billion remained with the respective treasuries. The producer support estimate averaged $\$ 248$ billion during 1999-2001.

On a commodity basis, the largest beneficiary was the milk industry ( $\$ 42.1$ billion in 1999-2001), followed by beef ( $\$ 27$ billion), rice ( $\$ 26$ billion), wheat ( $\$ 13$ billion), and pig meat ( $\$ 10$ billion). The three top subsidized commodities by a single country/region are $\$ 21$ billion for beef in the European Union, \$18 billion for rice in Japan, and \$17 billion for milk in the European Union (the subsidies to the beef and milk industries have been subject to political rhetoric, see box 1). Not all commodities are included in the PSE but the market price support is prorated upward for all of agriculture. One notable exception is cotton, whose annual budgetary outlays in the United States and the European Union averaged $\$ 4$ billion during 1999-2001.

A number of middle-income countries support agriculture (see table 5). For example, in 1999-2001 total transfers to agriculture averaged $\$ 21.4$ billion in Korea, $\$ 7.0$ billion in Mexico, $\$ 1.9$ billion in Poland, and $\$ 9.6$ billion in Turkey. Although these numbers seem small compared to the combined total transfers of $\$ 273$ billion made by the European Union, United States, and Japan, when considering this support as a proportion to the GDP of these countries, the results are striking: 5.0 percent in Korea and 5.1 percent in Turkey, almost 4 times the OECD average of 1.3 percent. Support per full time farmer averaged $\$ 25,000$ per annum in Korea, more than twice the OECD average of $\$ 11,000$.

Developing countries generally taxed agriculture before major policy reforms in the mid-1980s with import barriers on inputs, overvalued exchange rates and parastatal marketing boards and price controls/export taxes for individual commodity sectors. Most developing countries generate the bulk of agricultural GDP in lower efficiency production for the domestic market, supplying the world market with tropical commodities. Limited amounts are exported under preferential-access programs in products for which they competed with industrial countries, such as sugar and beef. But in the last decade, developing countries shifted from taxing agriculture to protecting it. Import restrictions on manufactured products have declined dramatically, exchange rates have been devalued, multiple exchange rate systems penalizing agriculture have been abandoned, and export taxes have effectively disappeared (Jansen et al. 2002; Quiroz and Opazo 2000; World Bank 2003).

Protection for agriculture seems higher for developing countries if comparing average tariffs but several difficulties make agricultural tariff calculations difficult. While some tariffs are underestimated, others are overestimated because of 'phantom' tariff lines -i.e., many tariff lines within a commodity category are redundant either because the country is an exporter of that commodity in question or imports are not directly competing with the domestic commodity that is being protected (Aksoy 2004). For example, China and India have high tariffs on products which are exported. Other reasons abound. For example, there can be imports due to seasonal swings in world prices, due to 
regional differences in domestic prices (one part of China is a natural exporter; the other an importer), or due to differentiated products. But even with imports in these circumstances, the country is often an exporter in different markets or at autarky, thus tariffs contain "water" in the sense that they do not actually protect. Developed countries, on the other hand, have high tariffs only on commodities that directly compete with domestic production so the tariff equivalent rate of protection as reported by the OECD is much higher than average tariffs for these same countries (World Bank 2003). Meanwhile, studies show that countries like India and China have been taxing agriculture on average in the last ten years (see, for example, Orden and Mullen 2004).

OECD (2001) has ranked the various producer support measures based on their relative impact on production and trade. The highest impact comes from input use, followed (in order of less impact) by market price support, payments based on output, area, historical entitlements, input constraints, and overall farm income. While the OECD does not link this ranking to its (or other) definition of decoupled support, one may argue that payments based on area, historical entitlements, input constraints, and farm income are decoupled from current production decisions and hence have a 'smaller' impact on production and trade. Correspondingly payments based on output and input use have a 'large' impact on production and trade.

Table 6 decomposes PSE into market price support and budgetary support for the 1986-88 and the 1999-2001 periods. Likewise, table 7 decomposes Producer Support into 'smaller' and 'large' impact on production and trade for the same periods. A number of interesting findings emerge from the tables. First, producer support has remained at similar levels in nominal terms. Second, there has been a small shift from border support

measures to domestic measures (market price support averaged 77 percent of PSE during 1986-88 and 64 percent during 1999-2001). Third, there has been a noticeable shift from support with high impact on production and trade to support with smaller impact on production and trade (the latter accounted for 91 percent during 1986-88 and 79 percent during 1999-2001).

In conclusion, it should be emphasized again what the PSE does and what it does not do. The PSE answers two questions: (i) What is the level of the transfers to agriculture? (ii) What is the direction of these transfers? However, it does not answer the following three questions: (i) Who are the end beneficiaries of these transfers? (ii) What is the impact of these transfers on production and trade? (iii) What is the social cost of these transfers?

\section{Consequences of Agricultural Support}

One of the main problems of the existing income transfer mechanisms is the efficiency losses. For example, the imposition of an import tariff, in addition to transferring income from consumers to producers and the treasury, also raises domestic prices consequently using resources to produce the commodity domestically that would otherwise have been 
imported at lower cost. These are the so-called dead-weight losses. Export subsidies have similar inefficiency effects in that both production and consumption are distorted. Domestic subsidies only affect production directly and so they are considered in general less distorting than border measures (see the general theory of domestic divergences in Corden 1974 and Feenstra 1986).

According to OECD, no support policy linked to agricultural activity succeeds in delivering more than half the monetary transfers from consumers and taxpayers as additional income to farm households. In the case of market price support and deficiency payments, the share is one-fourth or less; for input subsidies it is less than one-fifth (see table 8). Only 25 percent of producer support on average actually reaches the farmers.

In the case of market price support and deficiency payments, the stimulus to output, and hence to input demand, implies that much of the increase in revenue is paid back out to input suppliers or capitalized into land values. Not surprisingly, input suppliers receive most of the benefits of input subsidies. In the case of area payments, nearly all the benefits are absorbed in increased land values. This raises costs for farmers buying or leasing land. Farmers that own land do benefit, but this increase in wealth should not be interpreted as additional income, since it does not improve the long-term economic welfare of farm households as a whole. While there is a wealth gain for farmers that own land at the time such policies are introduced, farmers who subsequently rent or purchase land at these higher prices will face reduced profitability and lower incomes (OECD, 2003c).

The portion of domestic support that is capitalized into land values depends not only on the type of subsidy program but on the economic characteristics of the commodity sector in question like the share of land costs in the total costs of production, the elasticity of supply of the inputs, and the elasticity of substitution between land and nonland inputs. If land is very inelastic in supply and a large share of total costs, then the benefits of a subsidy program will have larger impacts on the price of land (especially if the elasticity of substitution between land and non-land inputs is low).

As for differing types of subsidies, a subsidy on purchased inputs has a lower impact on land prices than a subsidy on output, both of which have a lower impact than an area payment (a direct subsidy to land in the form of historical entitlement payments). The OECD provides estimates of the distribution of benefits for these three types of programs and finds that 91 percent of area payments go to land, while only 26 percent of price support payments and 18 percent of input subsidies. In each case, almost half of the benefit goes to the landowner and the other half as returns to land for farm operators.

The distribution of benefits going to land owners is an important policy issue because up to 45 percent of land in the United States is operated by someone other than the landowner, with over half of the latter being non-farmers. If a large proportion of the benefits go to land owners and not farm operators, then the desired effect of helping farm families is mitigated. Numerous studies have shown that a large portion of subsidies are 
capitalized into land values. ${ }^{3}$ Estimates of the change in the price of land due to subsidy programs in the United States are in the range of 10 to 40 percent. Gardner (2002) estimates that $\$ 1$ of payments generates $\$ 3$ of land value.

Agricultural policies of major producers also have important international spillovers. Existing policies provide significant incentives to produce, thereby increasing global supplies and lowering world prices, to the detriment of suppliers that receive no subsidies. A telling example of these spillover effects is the recent cases in the cotton industry brought to the WTO by Brazil and four West Africa cotton producers whereby they argued that subsidies given to the cotton sector of industrial countries affect the world price and hence cause injury to non-subsidized cotton producers. As well, trade policies, in particular prohibitive tariffs but also export competition policies that convey advantages to domestic suppliers, are in place to enable many of the existing domestic support policies to continue to operate. This is particularly the case for commodities where prices are supported above the level at which imports would be available if markets were more open. The long-term trend of agricultural productivity growing more rapidly than demand implies continued adjustment pressures at the global level. Trade protection does not change this fact; it simply shifts the burden of adjustment, in this case, to non-subsidizing countries.

\section{Objectives of Agricultural Support}

Increasing farm income and saving the family farm is the most common stated objective of agricultural policies. However, a number of other objectives are also stated. Winters (1989-90) analyzed the economics of the officially stated cases for agricultural support in selected OECD countries. After surveying numerous official country documents, he found a number of stated objectives: ensure satisfactory and equitable standard of living for farmers; stabilize income; stabilize domestic agricultural prices; ease adjustment to exogenous shocks; maintain healthy rural communities; boost regional development; preserve and encourage family farming; protect the environment; ensure stable and sufficient food supplies; ensure fair prices to consumers; improve agricultural efficiency and competitiveness. More recently ABARE (2001) gave the following four motives, which drive agricultural support in the United States and the European Union: (i) maintain current farm lifestyle; (ii) provide preferential access; (iii) link support to environment; (iv) expand market access abroad.

Some of these objectives have been brought together under the umbrella of multifunctionality, which according to OECD (2001b, p. 11) is an economic activity that "may have multiple outputs and, by virtue of this, may contribute to several societal objectives at once. Multifunctionality is thus an activity oriented concept that refers to specific properties of the production process and its multiple outputs." The key elements of multifunctionality are (again, according to OECD, p. 13): "The existence of multiple commodity and non-commodity outputs that are jointly produced by agriculture and the fact that 
some of the non-commodity outputs exhibit the characteristics of externalities of public goods, with the result that markets of these goods do not exist or function poorly." Vatn (2002) outlines a broader list of the various public aspects of a multifunctional agriculture which includes environmental effects such as landscape (biological diversity, recreation, aesthetics), cultural heritage, pollution (changes in matter cycles, genetic pollution, etc.); food security (availability in different situations); food safety (quality and phytosanitary status); and rural concerns (rural settlement, rural economic activity).

Yet the objective of increasing the income of small farmers fails to be met as there is a well-documented gap between intended and actual transfers. There are two sources of the gap: (i) economic costs, which result from distortions in the use of resources and its incidence on production and trade patterns and (ii) distributive leakages, whereby some of the benefits of support accrue to groups other than the intended beneficiaries. This latter category includes benefits accruing to bureaucrats administering programs, input suppliers or downstream industries, and landowners, as discussed earlier. When the country in question is large, such as the United States and the European Union, there are international spillovers whereby large quantities of the subsidized commodities are directed into the world markets consequently depressing prices. The sum of these 'unilateral' policies in depressing world prices can cause some countries to react by raising their protection or subsidies to compensate, thereby contributing to the ever increasing downward spiral in world prices.

\section{Disciplining Agricultural Support}

Disciplining agricultural support falls under the three pillars introduced earlier. This particular classification does not necessarily reflect any economic significance in terms of what type of support is most damaging or where priority for reform should be given. It just reflects the realities at the time as well as the complicated nature of agricultural support. ${ }^{4}$ Nevertheless, as Roberts (2003) noted, having separate pillars made negotiations manageable and ensured that all forms of assistance were covered.

The WTO classifies domestic support into measures which are disciplined and thus subject to reduction commitments (also known as Amber box payments) and measures which are exempted from reduction commitments. ${ }^{5}$ The Amber box includes market

price support as well as some product- and non-product-specific budgetary outlays (see figure 2).

Support which is not subject to reduction commitments consists of the following:

- Green box. It includes non-distorting payment programs which are not subject to reduction commitments such as decoupled income support to farmers, general government services (e.g., research, disease control, infrastructure and food security stockholding), direct payments for environmental improvement, and structural adjustment and regional assistance.

- Blue box. It includes payments which are exempt from reduction commitments that 
limit production with the use of a fixed base of land area, crop yields, number of head of livestock, or production.

- de minimis payments. They do not exceed 5 (10) percent for developed (developing) countries of the value of production of individual products and 5 percent (10) percent in developed (developing) countries of the value of total agricultural production for non-product-specific support;

- Development programs. Measures which encourage agricultural and rural development in developing countries.

An important element of the URAA was the Peace Clause which expired at the end of 2003. It specified that domestic support policies were non-actionable (e.g., no countervailing duties). A wider list of policies of developing countries is exempt and some least developed countries are exempt from any subsidy reduction commitments.

In order to monitor compliance with the reduction commitments, the Aggregate Measurement of Support (AMS) has been devised. It is defined as:

An index that measures the monetary value of the extent of government support to the sector. The AMS as defined in the [Uruguay Round] Agreement on Agriculture, includes both budgetary outlays as well as revenue transfers from consumers to producers as a result of policies that distort market prices. The AMS includes actual or calculated amounts of direct payments to producers (such as deficiency payments), input subsidies (on irrigation water, for example), the estimated value of revenues transferred from consumers to producers as a result of policies that distort market prices (market price supports), and interest subsidies on commodity loan programs.

Each country's AMS was agreed to be reduced by 20 percent from a 1986-88 base over a 6-year period (1995 to 2000). The AMS reduction commitment for developing countries is 13.3 percent over a 10-year implementation period. To illustrate, table 9 reports the WTO notifications of the European Union, United States, Japan, Korea, and Canada for 1999. The first two rows include support under the Green and Blue Box which is not subject to reduction commitments. The third row reports the sum of the product and non-product specific de minimis exemptions. The two rows under the heading "Support Included in AMS" denote the share of the AMS that comes from taxpayer funded subsidies and consumer transfers through higher market prices resulting from border protection.

Several conclusions emerge from table 9. Perhaps, the most important one is that consumer transfers account for a substantial part of the AMS. For example, during 1999, they accounted for 96 and 83 percent in the European Union and Japan, respectively. The share for the United States was 35 percent. Another conclusion is that the US is the largest user of the green box and de minimis exemptions. Third, the notified AMS is well below the ceiling, implying that substantial cuts in the AMS will be required for an actual reduction in support to take place.

The implication of the figures reported in table 9 are not surprising considering the way in which the consumer transfer component of the AMS is calculated, that is, as 
$\left(P_{t}{ }^{\text {official }}-P_{1986-88}\right)^{*} Q_{t}{ }^{\text {eligible }}$. Note all three variables of interest, i.e., the current official price, the 1986-88 world reference price, and the quantity eligible for support may or may not have anything to do with the actual level of border protection. ${ }^{6}$ Hence, countries are able to adjust official administered prices in order to "achieve" reduction commitments without necessarily reducing support. A telling example of how poor measure of support the AMS can become is the decision by Japan to lower the "official" price or rice, effectively reducing its AMS notification to the WTO from $\$ 26.2$ billion in 1997 to $\$ 5.9$ billion in 1998, without actually changing the actual level of support. In fact, PSE remained almost unchanged during these two years (see table 10). ${ }^{7}$ 


\section{DECOUPLING AS A CONCEPT}

Broadly speaking, decoupling is the move from support based on current production (and hence trade-distorting) decisions to support not based on current production (and thus not trade-distorting) decisions. This definition, however, while it specifies where income transfers should not be linked to, it does not specify where they should be linked to. Furthermore, it does not say anything about the way in which decoupled payments are financed. On the other hand, it is important to emphasize that because decoupled support is not affected by production decisions, it does not necessarily imply that decoupled support does not affect production decisions. This section elaborates on the definitional issues regarding the concept of decoupling as well as the economics of decoupling, especially relating to the source of funding.

\section{What Is Decoupling?}

Decoupling has different meanings to economists, policymakers, and trade negotiators. Some see it as a transition mechanism to a fully competitive sector. Others see it as another support program, with less production- and trade-distorting effects. Some use decoupling only to refer to programs for transferring income to producers; others use it much more broadly, to include, for example, programs to improve the environment. Sometimes decoupling is assessed according to the policy's long-run impact on output through such factors as uncertainty, investment, and expectations.

Although decoupling has been discussed in the academic literature as early as 1946 (see box 3), perhaps the first analyst to explicitly advocate a well-defined decoupled support program in the U.S. agriculture was Swerling (1959). ${ }^{8}$ Two characteristics of Swerling's proposal are especially interesting. First, he advocated a safety net mechanism for agriculture, similar to safety nets in other sectors of the economy (such as unemployment insurance). Second, he proposed linking the benefits of the decoupled support to income declared in tax returns during the recent past, not to historical production or area, which was the common recommendation defined in other decoupling proposals. ${ }^{9}$

Another early decoupling proposal was put forward by Nash in Europe: (1961, p. 188):10

Instead of obstructing the withdrawal of farmers from an industry which cannot adequately reward them, ... an unconditional payment to all those at present engaged in farming, or to those of them deemed to be need of compensation, calculated by the reference to the difference between the incomes now earned under the protective system and those capable of being earned under a system of free market prices. An annuity calculated in this way and payable for life to all engaged in farming, but not transferable to their successors, would, in theory at least, make it possible to bring the protective system to an end while fully making good the loss of income to its present beneficiaries. There is no doubt that compensation of this kind is feasible-a scheme with some resemblances to the present proposal has in fact been applied to the cotton industry; ${ }^{11}$ and even if it resulted in continuing liabilities for a lengthy transitional period it would be greatly preferable to 
the indefinite retention of the existing protective system.

Van Riemsdijk (1973) questioned the purpose of the Common Agricultural Policy (CAP) in Europe and argued that it must be changed fundamentally towards a direct compensation system and asked (p. 164): “... what kind of action should be taken to get agriculture adapted to the lower prices in such a way that it will be able to provide itself income parity by means of its own capabilities, i.e., without getting more help than is offered by a market and price policy designed to smooth price variations of an undistorted world market and to avoid any other form of protection."

The proceedings of the workshop "Decoupling: The Concept and Its Future in Canada" contains numerous definitions of decoupling (Finkle and Cameron 1990). Consider the following two rather contrasting views. Van Donkersgoed (1988) of the Christian Farmers Foundation of Ontario defined decoupling as (p. 40): "a program in which eligibility is not linked to production, the production potential of resources or the production effort of a farm entrepreneur; rather eligibility is linked to stewardship farming practices, marketing, the maintenance of rural communities, diversified ownership of the assets of production, moderate-sized family enterprises and other rural, non-production valuables that add to the quality of Canadian life." Spriggs and Sigurdson (1988) on the other hand, simply stated (p. 93): "In fact, a program to eliminate subsidies would be the ultimate in decoupling. It is the only truly decoupled program that there is."

Cahill (1997, p. 351) defines a policy as fully decoupled from production that "does not influence production decisions of farmers receiving payments, and that permits free market determination of prices (facing all farmers, whether or not receiving income support)." A policy is effectively fully decoupled if "the provision of the compensatory payment package results in production that, for any crop, does not exceed that level that would exist without compensation." OECD (2000a) defines decoupling in a similar way. The US Department of Agriculture (2003) refers to decoupled payments as lumpsum income transfers to farm operators that do not depend on current production, factor use, or commodity prices and for which eligibility is based on fixed, historical criteria (USDA 2003).

Hennessy (1998) includes as decoupling payments triggered by ex post market or production conditions, as long as the payment level is not conditioned on an individual's specific level of production. Disaster relief measures, for example, would be considered decoupled because they are not affected by the individual's level of production.

Goodwin and Mishra (2002) argue that a fully decoupled payment must be fixed and guaranteed and thus is not influenced by ex post realizations of market conditions (such as low prices or area yields). This is the most narrow definition because neither payments nor the rules of eligibility and the base criteria can be changed. If a time limit is added to this definition, then decoupling simply implies a number of annual payments to producers. Where financial markets function efficiently, these bonds can be converted into a single payment. In such a setting, decoupling would consist of an administrative 
decision to remove distortions followed by a single payment-a radical, but sensible, policy initiative.

Swinbank (2004) advocated a decoupling proposal for the CAP in which farmers would be guaranteed a future stream of payments, akin to a government bond, the discounted present value of which could be traded in the stock exchange. Under their 'bond scheme' "... farmers would no longer have to sow crops or keep livestock to qualify for the annual payments, or even farm their land." (p. 1).12

The Uruguay Round Agreement on Agriculture (URAA) uses the term decoupling in connection with direct payments to producers that satisfy the following conditions (URAA Annex 2.6):

Eligibility for such payments shall be determined by clearly-defined criteria such as income, status as a producer or landowner, factor use or production level in a defined and fixed base period. The amount of such payments in any given year shall not be related to, or based on, the type or volume of production (including livestock units) undertaken by the producer in any year after the base period. The amount of such payments in any given year shall not be related to, or based on, the prices, domestic or international, applying to any production undertaken in any year after the base period. The amount of such payments in any given year shall not be related to, or based on, the factors of production employed in any year after the base period. No production shall be required in order to receive such payments.

According to this definition, payment levels can technically change with market prices, as long as production is not related to these changes. The key factor is that the rules for eligibility and the criteria upon which payments are based upon originally (like the volume of production or use of input or status of a farmer) cannot change once the decoupled program is set in place.

The above definition of decoupling is for payments motivated by farm income concerns only. If the rationale for the policy is to correct for market failures and provide public goods, then the definition of decoupling above is inappropriate. Policies correcting for market failures or providing public goods require effects on production like pollution reductions and so should be analyzed in a different context, namely, minimal trade distorting. Because governments have consolidated these two motives in their call for exempting direct payments or border protection to fulfill the multiplicity of goals under the rubric of 'multifunctionality', it is important to keep the distinction and ensure that farm income goals are not achieved through the back door under the rubric of multifunctionality.

Payments are decoupled as defined by the URAA, if eligibility is clearly defined by criteria in a defined and fixed base period, where production is not required nor related to the type or volume of production after the base period. Payment levels can change with market prices, but funds to finance such transfers can only be obtained from taxpayers. The key factor is that the rules for eligibility and the criteria upon which payments are based upon originally (like the volume of production or use of input or status 
of a farmer) cannot change once the program is set in place.

Notice that this definition of decoupling concerns with the disbursement of payments to farmers, not the effects of raising the taxpayer funds in the first place. The URAA, however, does not exclude taxpayer transfers funded from a specific tax on the individual commodity for which the producer is receiving the decoupled payment-the only transfer that is prohibited is a direct transfer from the consumer to the farmer in the same market through, for example, a price support scheme. A consumer tax on tobacco that goes into the general treasury is perfectly legitimate while at the same time having decoupled support payments to tobacco farmers that come from the same general pool of funds for all taxpayer expenditures.

The definition of "decoupling" does not include all programs in the green box because the latter includes expenditures that always do not involve direct payments to agricultural producers (e.g., food aid). Neither does 'decoupling' always refer to direct payments to producers in the green box because several programs (e.g., environmental) involve direct payments to producers but inevitably vary with the type and volume of inputs and output in order to achieve a particular level of environmental benefit (which itself can change from year to year). Direct payments under an environmental program therefore can have significant effects on production. Nevertheless, trade can be distorted because a 'polluter pay' principle will have production occur in countries with comparative advantage and hence minimize trade distortions.

Hence, the URAA definition of decoupling is more than specific enough to fulfill strict economic definitions of decoupling due to production and consumption effects of direct payments designed to transfer income to farmers. But the condoning of payments to farmers for other programs that correct for market failures or provide public goods can have a deleterious effect on international trade and have production in regions that do not have comparative advantage. The rule for payments under environmental programs merely states: "The amount of payment shall be limited to the extra costs or loss of income involved in complying with the government program."

\section{The Economics of Decoupling}

Decoupling can be viewed as two distinct transition mechanisms: one replacing domestic support and one replacing border measures. The key variable driving this distinction is the source of financing for the original support measures: consumers, taxpayers, or a combination. In what follows, the welfare implications of moving from coupled to decoupled support are discussed for the case of a production subsidy and an import tariff. The discussion is followed by the marginal excess burden of taxation, and lastly by the implications of decoupling at a micro level. Because decoupling in the case of replacing border measures requires changing the structure of taxation (from a consumption tax to other type of tax as well as ruction in tariff revenue), any decoupling proposal must involve decisions made by the ministry of finance, in addition to the ministry of agriculture 
and trade. To illustrate the importance of this issue, box 3 outlines a hypothetical conversation between an agriculture and finance minister on the issue of decoupling.

\section{Decoupling as a Subsidy Disbursing Mechanism}

Let $D_{d} D_{d}$ and $S_{d} S_{d}$ denote domestic demand and supply of the commodity in question for an exporter (figure 3). In a closed economy setting the market clears at quantity and price dictated by the intersection of domestic demand and supply (panel A). If the economy is open and small, the price is $P_{m}$ as dictated by the intersection of the exporter's supply to the world $\left(S_{w}\right)$ and the demand schedule of the rest of the world $\left(D_{w}\right)$ (panel B). Because of the small country assumption, the demand of the rest of the word is depicted in panel $B$ as a horizontal line. Domestic producers supply $O Q_{1}$. Domestic consumption is $O Q_{0}$ and the remaining $\left(Q_{0} Q_{1}\right)$ is exported. This is the competitive outcome.

Assume now that the policy maker's objective is to increase producer's income. One way to accomplish this is to introduce a production subsidy, say, $s\left(=P_{s}-P_{m}\right)$ Following the introduction of the subsidy, producers will receive $P_{s}$ and they will supply $Q_{3}$. Again, under the small country assumption the world price will not change (i.e. it will remain at $P_{m}$ ). Domestic consumers will demand $Q_{0}$ (as previously) and pay $P_{m}$ while $Q_{0} Q_{3}$ will be exported. The welfare implications of this policy move are straightforward. The cost of the subsidy (i.e. the cost to taxpayers) is the rectangular area $\alpha+\beta+\gamma$. The increase in revenues to producers is the area $\alpha+\beta+\gamma+\eta+\theta$. Total costs of production increase by the area $\gamma+\eta+\theta$ so the net gain to producers is the area $\alpha+\beta$. The triangle $\gamma$ corresponds to the deadweight loss for producing the additional output at a higher cost than the competitive price $P_{m}$.

The idea of decoupling in this setting is simple. Producers receive $\alpha+\beta$ and part of $\gamma$ in lump sum form and hence they are made better off. Taxpayers retain the remaining of $\gamma$ and they are also better off. Hence, the move is deemed Pareto improvement as both producers and taxpayers are better off while the welfare of the consumers does not change since they consume the same amount and pay the same prices.

If the country is a large player in the commodity market in question, then the demand curve facing the country is downward slopping $\left(D^{\prime} w\right.$ in panel B). This implies that following the introduction of the subsidy the world price will decline from $P_{m}$ to $P_{w}$. There a number of additional welfare implications. First, taxpayers pay more since the cost of the subsidy increases by the rectangular are defined between $P_{m}$ and $P_{w}$ and to the left of $Q_{3}$. Second, domestic consumers gain the trapezoidal area $\delta$ because they face lower prices. Third, the triangular area $\varepsilon$ becomes the consumer's deadweight loss of overconsumption. Finally, the rectangular area $\zeta+\eta$ become welfare transfers to foreign consumers. The implications of decoupling in this case are also more complex since Pareto optimality in this setting would involve transfers to/from foreign producers and consumers as well as domestic consumers who now consume more and pay less.

Now suppose that the country in question is a net importer and protection takes 
the form of an import tariff (figure 4). Let $D_{d} D_{d}$ and $S_{d} S_{d}$ denote domestic demand and supply of the commodity in question. In a closed economy the market clears at quantity and price dictated by the intersection of domestic demand and supply. If the economy is open and small, price is $P_{m}$, and the supply for the commodity becomes $S_{d} S_{m}$. Domestic producers supply $O Q_{1}$, while the remaining $\left(O_{1} Q_{0}\right)$ is imported. This is the competitive outcome.

Assume now that the policy maker's objective is to increase producers' income. One way to accomplish this it is to introduce an import tariff, say, $t$. Following the introduction of the tariff, the domestic supply schedule becomes $S_{d} S_{d}$. At $P_{t}$ (the new price), consumers will demand $Q_{2}$. Domestic producers will supply $O Q_{3}$ while the remaining $\left(Q_{3} Q_{2}\right)$ is imported. An import tariff has three resource allocation-related effects: First, consumers pay a higher price (from $P_{m}$ to $P_{t}$ ) and consequently demand less (from $O Q_{0}$ to $\mathrm{OQ}_{2}$ ). Second, domestic producers receive a higher price and hence produce more (from $O Q_{1}$ to $O Q_{3}$ ). Third, the treasury receives tariff revenue $\gamma$ (equal to the tariff rate times the quantity imported).

The monetary burden on consumers (reduction in consumer surplus) due to the tariff is the rectangular area $\alpha+\beta+\gamma$ of which the area $\gamma$ (the tariff revenue) goes to the treasury; the trapezoidal area $\alpha$ (the change in producer surplus or change in profits) goes to the producers; the triangular area $\beta$ (the excess cost of producing the additional output $\left.Q_{1} Q_{3}\right)$ is the deadweight loss, that is, the additional resources required to produce domestically the commodity that would have been saved, had the corresponding amount of the commodity been imported. Finally, the triangular area $\delta$ denotes the welfare loss to consumers, or reduction in consumer surplus that is not offset by revenue to the treasury. Total deadweight losses equal the sum of the two triangles $(\beta+\delta)$.

A similar outcome would arise if, instead of taxing imports, the country limits the imported quantity to $Q_{3} Q_{2}$. The importers then receive a rent equivalent to the tariff revenue net of the cost of obtaining an import license. Under certain assumptions, importers competing for the import licenses would pay the same in the aggregate for licenses as the tariff forgone. Alternatively, the quota can be allocated to a certain exporters, a common practice employed as an aid tool through preferential trade arrangements whereby only a few countries are allowed to fulfill the quota.

Decoupled support calls for: (i) eliminating the tariff, (ii) raising additional taxes, and (iii) redistributing these taxes as a lump-sum transfers to producers. Producers plus importers (consumers) supply (demand) $O Q_{0}$ at price $P_{m}$ as in the no-tariff scenario. Producers receive as compensation for their "losses" the lump-sum transfer $\alpha$ plus part of the triangular area $\beta$ and therefore are better off; the treasury receives the area $\gamma$ and therefore is better off; consumers save $\alpha+\beta+\gamma$-part of which was transferred to producers and part to the treasury - but they retain the remaining part of the two triangular areas and therefore are better off. Thus, from a sectoral point of view, the move to decoupling is a Pareto improvement. However, Pareto improvement cannot be established from 
an economy-wide point of view because taxpayers are worse off-note that the burden of support shifts from one group (consumers) to another (taxpayers). The next section discusses this issue.

If the country is an important player in the world market, it faces an upward sloping supply schedule (panel 2, figure 4). Numerous welfare changes will take place following the introduction of a tariff, in addition to those outlined in the small country case. First, because quantities of the commodity that would otherwise have been imported will be diverted into the world market, the world price will decline from $P_{m}$ to $P_{w}$, implying that the welfare of other exporters will decline. Second, a higher tariff is required now in order to maintain the same level of income to producers $\left(P_{t}-P_{w}\right.$ instead of $\left.P_{t}-P_{m}\right)$. Third, the treasury gains the additional area $\varepsilon$ because of the higher tariff.

The effects subsidies in the large country case were exemplified recently by a number of developments in the cotton market. On September 27, 2002, Brazil requested consultation with the United States regarding export subsidies and domestic support provided to its United States cotton industry (see box 4). ${ }^{13}$ The WTO panel ruled in favor of Brazil, concluding that that United States should withdraw the export subsidies and the export credit guarantees given to its cotton industry. The panel also ruled regarding domestic support that "the US is under an obligation to take appropriate steps to the adverse effects or withdraw the subsidy" (WTO 2004, pp. 351).

In a similar move, four West African cotton producing countries-Benin, Burkina Faso, Chad, and Mali-submitted a joint proposal to the WTO on April 31, 2003 asking for compensation for losses in export revenues incurred because of the subsidies given to the cotton sectors of rich countries (the so-called 'cotton initiative', see box 5). In terms of figure 3 (assuming that the left panel represents the cotton sector of the United States and the right panel represents the cotton sectors of the four West African countries), the compensation by the four West African countries would consist of the product of the price difference $\left(P_{m}-P_{w}\right)$ times the loss in the export share (the maximum of which is the difference between $X_{2}$, the "competitive" export quantity, and $X_{0}$, actual exports).

\section{Decoupling and the Costs of Taxpayer Funds}

The discussion on decoupling so far has focused primarily on disbursing taxes. Decoupling, however, implies that support will be financed entirely by the treasury. The portion of the decoupled support that replaces budgetary outlays (e.g. direct subsidies) does not introduce any new equity or efficiency issues in terms of raising the funds since the decoupled support will be financed entirely by existing taxes - hence the Pareto improvement outcome in the production subsidy case. However, the portion of decoupled support that replaces border measures (e.g. tariffs) requires new funds from the treasury and hence new taxes or higher tax rates of existing taxes. Unless these new taxes are lumpsum (i.e. decoupled from labor and consumption decisions), they will create their own deadweight losses, which is why establishing Pareto improvement in this case requires 
strong assumptions regarding the relative size of deadweight losses. ${ }^{14}$ This is a very important issue, especially considering that two thirds of the OECD support to agriculture is in the form of border protection. ${ }^{15}$

The issue of shifting taxation to finance decoupled programs has generated some skepticism among economists regarding the efficiency of decoupling as a policy alternative. Consider, for example, what Munk (1989, p. 88) contends:

For a system of transfer payments to be lump-sum it needs to be non-distortive on both the revenue side and the expenditure side. No government obtains a sizeable share of its tax revenue from lump-sum taxes and there are no compelling reasons why a system of lump sum transfers to agricultural households, financed by, say, ordinary income taxation, should be superior to other support instruments. This tends often to be forgotten by advocates of direct income support.

Alston and Hurd (1990, p. 155) echoed similar thinking:

Currently it is fashionable to argue for 'decoupling' farm programs in the sense that income transfers should be achieved with minimal consequences for commodity markets. Along with the benefits from transparency, the benefits from decoupling may be illusory. The issue here is whether the costs of distortions in commodity markets are necessarily greater than the costs of distortions introduced elsewhere in the economy to finance 'decoupled' transfers.

Moschini and Sckokai (1994), however, argued that the welfare losses of raising new taxes to finance decoupling are unlikely to be larger than the welfare gains from decoupling. Winters (1989-90) argued that unless the outlays are very high, it is unlikely that other support measures will outweigh the advantages of a direct income support.

In terms of empirical estimates, Beghin el al. (2003) found that in Korea it costs taxpayers $\$ 1.61$ for every $\$ 1$ transferred to agricultural producers. Using a general equilibrium model, Parry (1997) concluded that the efficiency cost of taxpayer-financed lumpsum transfers to agriculture equals 27 percent of the amount of the income transfer. Feldstein (1999), however, argued that traditional analyses of the income tax greatly underestimate deadweight losses by ignoring its effect on forms of compensation and patterns of consumption. The relative deadweight loss caused by increasing existing tax rates may exceed $\$ 2$ per $\$ 1$ of revenue raised.

Since most of the support is at the border, decoupling may not always result in a welfare improvement, depending critically on the marginal excess burden of taxpayer financed funds relative to that of consumer financed transfers. It should be noted that the latter could also be high with rent seeking so it is not a foregone conclusion that taxpayer financed funds are more costly (Krueger 1974). However, special consideration should be given for developing countries without adequate income tax infrastructure whereby consumer transfers through import taxes can be more efficient. Otherwise, decoupled schemes should be encouraged, even with a higher marginal excess burden of taxation, given the lower distortions in world commodity prices and trade with decoupled payments. But there is a political economy issue here in that governments may face higher 
tax costs to maintain the same level of farm income and lose a potentially lucrative source of tax revenues through import tariffs. Higher tax costs and lower tax revenues can expose governments to political opposition while import tariffs are less visible and so less prone to create political opposition.

\section{The Micro-Side of Decoupling}

While Pareto optimality may be achieved in the case of moving from production subsidy to decoupled payments, when it comes to actual implementation, this may no longer be the case. To see this, consider the following simplified setting. A 50-hectare wheat producing farm, with yield of 1.5 tons per hectare would make $\$ 15,000$ when the price of wheat is $\$ 200$ per ton. A price support mechanism of $\$ 50$ per ton would boost income to $\$ 18,750$, assuming output does not change. Now assume that instead, a $\$ 100$ per hectare decoupled support is given. That would boost income to $\$ 20,000$, a net gain of $\$ 1,250$ (see table 11). The benefit of this decoupled payment based on land may all go to the landowner in the form of higher land rental rates so farm operators may not receive any benefits, and at most, only part of the subsidy.

Now suppose that an upper limit of 100 hectares is imposed, implying that for any hectare above that limit producers receive no support. In such a scenario, owners of farms above 100 hectares realize losses compared to an open ended production subsidy or price support. As shown in Table 11, the larger the farm, the more loss it incurs compared to a price support.

To make the reform politically feasible, sometimes decoupled programs become very expensive policy instruments. As mentioned earlier, one of the main reasons behind the Brannan's Plan failure in the United States was that it lost political support due to high potential cost. As it will be discussed later, concerns regarding the costs of Mexico's decoupled program were raised as soon as the program was discussed. It been argued very often that the United States was able to proceed with the 1996 Farm Bill, because of high commodity prices, which in turn made the program expensive considering that consumers were paying high prices and taxpayers were financing decoupled payments. ${ }^{16}$ 


\section{DECOUPLING IN PRACTICE}

Early attempts at decoupling failed. The 1949 Brannan Plan in the United States, which proposed cash payments to farmers whose overall income fell below a certain level, was defeated in the U.S. Congress. Similarly in Europe, the Mansholt Plan of 1967, which advocated support in order to finance mandatory retirement for older farmers, also failed (see box 6 for a summary on these two plans). ${ }^{17}$

The first attempt at decoupling came in the United States with the 1985 Farm Bill, which shifted the base of support from current yields to historical yields. The European Union partially replaced intervention prices with direct payments following the Common Agricultural Policy reform of 1992. Mexico replaced price supports with direct payments in 1994 with the introduction of the National Program for Direct Assistance to Rural Areas (Programa de Apoyos Directos al Campo, or PROCAMPO). The United States replaced deficiency payments with decoupled support in the 1996 Farm Bill. More recently, Turkey replaced some price support and input subsidies with direct payments (table 12 outlines the chronology of significant decoupling and recoupling efforts while table 13 summarizes the characteristic of the main four decoupling programs). In addition to broad decoupling programs, there have been numerous one-time buyouts, including New Zealand's exit grant in 1984, the buyout of Canada's grain transportation subsidy in 1995, the buyout of the U.S. peanut marketing quota under the 2002 Farm Bill, and the 2004 tobacco buyout in the US.

\section{Experience with Broad Decoupling Attempts}

\section{Decoupling Efforts in the United States}

The budgetary outlays for most U.S. commodity programs are authorized by Congress (and subsequently approved by the president) every few years through farm bills. There have been 20 such bills since the first one of 1929. The central feature of the New Deal farm programs of the 1930s was price supports achieved through taxpayer-funded production subsidies and supply controls (acreage set-asides as well as accumulation, maintenance, and disposal of public stocks). Payments were based on the difference between the target price set by the government and the higher of the market price or the price at which the government would value crops used as collateral for loans made by a public corporation. The total payment was equal to the yield per acre multiplied by a farm's eligible payment acreage (the amount of land devoted to cultivation of the crop in question). This portfolio of policy instruments was the primary means of price support for the major field crops for decades until the 1980s.

The Food Security Act of 1985 set a new trend for major field crops by reducing the role of acreage set-asides and public stockholding and moving toward decoupling, with a "freeze" on payment yields (farmers were paid on the basis of fixed output per 
acre regardless of what actually was produced). Payment yield was established for each farm by the Department of Agriculture, based on average yields in 1981-85.

Acreage set-asides and public stockholding were largely abandoned by the mid1990s and eliminated soon thereafter with the introduction of the Federal Agricultural Improvement and Reform (FAIR) Act in 1996. FAIR also banished the target price used in calculating deficiency payments but maintained the lower fixed price, called the loan rate, which had triggered public stock purchases in the past. In place of the links between support, prices, and production, production flexibility contract payments were introduced. Participating producers received payments in proportion to what they had received during 1990-95, or would have received had they been enrolled. These historical benefits were in turn determined by a farmer's historical production levels. Each participating producer received a fixed schedule of payments, which was to gradually decline through 2002. Although not specifically stated, it was implicitly assumed that the payments would end by 2002.

The effect of the 1996 Farm Bill on the structure of budgetary outlays is shown in table 14. It breaks the producer support estimate down into market price support (a measure of border protection) and budgetary support (a measure of domestic support). Budgetary support is further decomposed into support based on output and input use (considered as having a large impact on production and trade, or fully coupled support) and support based on area, historical entitlements, input constraints, and overall farm income (considered as having a smaller impact on production and trade, or partially decoupled support; for further details and definitions, see OECD 2000b).

Historical entitlements, which did not exist before 1996, represented more than a third of total budgetary support in 1996-98. They are exempt from disciplines in the WTO since they are classified as "Green Box" payments. Area payments declined from $\$ 5.4$ billion in 1993-95 to $\$ 1.2$ billion in 1996-98 and are also exempt from reduction commitments in the WTO since they are under the "Blue Box" category. During these two periods, output payments under discipline in the WTO-listed as "Amber Box" payments - also increased, from $\$ 0.2$ billion to $\$ 1.6$ billion, a reflection primarily of declining commodity prices and consequently increased loan rate payments.

Although payments were made on a crop by crop basis, planting was not required or restricted to any particular crop. Payments were tied to 85 percent of the fixed base area (average of acres planted or prevented from being planted for covered crops of wheat, feed grains, rice, and cotton) and fixed payment yields. Because the payments were independent of current production, farmers had far greater flexibility to make planting decisions (or to not plant at all). Farmers were free to allocate their land to any crops on the "contract acres" except fruits and vegetables, but they had to maintain their land in agricultural use. Thus producers were to depend more heavily on the market and also bear greater risk from increased price variability.

The FAIR Act was meant to be a transition toward a new policy environment with 
a diminished government role in commodity markets. However, commodity prices declined sharply in the late 1990s, triggering three major policy shifts that reversed much of what had been accomplished by the FAIR Act. First, emergency payments were introduced, approximately equal to 50 percent of decoupled payments in 1998 and 100 percent of decoupled payments in 1999, 2000, and 2001. These were designated as nonproduct-specific support and so escaped reduction under the de minimis exception of the WTO. Second, when market prices fell below the loan rate, the government extended the marketing loan program by issuing loan deficiency payments, which had the same economic effects as the previous deficiency payment scheme. Third, the 2002 Farm Bill was introduced, increasing several loan rates, introducing three more crops into the loan rate scheme, and allowing base acres and payment yields to be updated and soybean acreage to be added to the base. The bill formalized the emergency payments into a new countercyclical scheme in which payments vary with price but not quantity.

The emergency measures introduced in 1998 (and later the 2002 Farm Bill) changed the structure of the budgetary outlays considerably. Between 1996-98 and 19992001 , historical entitlements increased by more than 50 percent (from $\$ 6.6$ to $\$ 10.1$ billion), area payments increased twofold, and payments based on output increased more than fivefold, implying that support is less decoupled now than it was after 1996.

\section{Decoupling Efforts in the European Union}

The principal vehicle of support in the European Union has been the Common Agricultural Policy (CAP). Following the Spaak Report of 1956, which suggested that agriculture requires special treatment, the Stresa Conference of 1958 outlined CAP's three guiding principles: free flow of agricultural commodities within the common market, preference to member states, and common financing. CAP, formally put in place in 1962, had multiple objectives: increase agricultural production, ensure a fair standard of living for the agricultural community, stabilize markets, guarantee a regular supply of agricultural commodities, and ensure reasonable prices for consumers. These objectives were to be achieved through domestic price support, export subsidies, and common trade barriers. The first and last objective were fully met within a few years and concerns were soon raised about excess production and the unsustainable level of CAP budgetary requirements if policies did not change.

Reform of the CAP was attempted in 1972, following the recommendations of the 1967 Mansholt Plan. The plan proposed, among other reforms, lump-sum transfers to 5 million farmers to retire them from farming and reduce active farmland by 5 percent. The Mansholt Plan, the first attempt to decouple, was never implemented.

The first major reinstrumentation of the CAP took place in $1992 .{ }^{18}$ For cereal, oilseed, and protein crops and for beef and veal, price supports provided by import levies or export refunds were reduced, and farmers were compensated with direct payments. For crops, payments were based on 85 percent of historical plantings (with a paid mini- 
mum area set-aside requirement, a further paid voluntary set-aside of up to 30 percent of historical area, and a base acre limit for payments set at the national or regional level). The area payment rates varied by crop type, and the set-aside payments were initially higher but are now equal. The only requirement is the land had to be set-aside or planted in crops or temporary grass. Small-scale farmers producing less than 92 tons of cereals are exempt from set-asides and receive an "all cereals" payments irrespective of crop planted (representing 25 percent of area but 70 percent of farmers).

Between 1986-88 and 1993-95 budgetary support in the European Union increased threefold, from $\$ 13.4$ billion to $\$ 40.3$ billion, while border support declined from $\$ 80$ billion to $\$ 76$ billion (see table 15). Most of the increase in budgetary support was due to area payments and, to a more limited extent, to historical entitlements and input constraints (designated "Blue Box" payments and so exempt from reductions in the WTO).

Following the 1992 reforms, the level of support remained unchanged, but its structure changed considerably. For example, while the PSE averaged $\$ 117$ billion for 1989-92 and 1992-95, border protection support declined from $\$ 93$ billion in 1989-92 to $\$ 76$ billion in 1993-95. Support based on output declined from $\$ 7$ billion to $\$ 3$ billion, and area payments increased from $\$ 7$ billion to $\$ 24$ billion. Thus, the 1992 CAP reform was a solid step toward decoupling.

Under Agenda 2000, price support to crops declined, direct payments increased and were realigned across all crops, and reference yields were changed in some countries. A push toward more investment in rural development was also made. A large transformation has occurred away from border protection and input subsidies to direct payments. Total support has been declining, especially in grains and oilseeds. More than the increase in budgetary allocations, which remains moderate compared with other expenditures, the growing importance of rural development seems to follow from the official reference to it as the "second pillar of the CAP."

The European Union now has greater flexibility to overhaul any policy element in light of changes in market developments, costs, enlargement, WTO (and other) trade negotiations, food crises, and other pressure for reform. The budget for Agenda 2000 did not include any provision for extending direct payments to farmers of the new member states, making reform a requirement. ${ }^{19}$ Meanwhile, the European Union has launched free trade negotiations with Mercosur, and it established the "Everything but Arms" (EBA) initiative with developing countries. Because of Mercosur (which includes some major agricultural exporting countries) and EBA, imports of agricultural products in the European Union (such as sugar, rice, and bananas) are likely to increase so further reform of the CAP may be necessary.

Recent food crises underline the need for reform, sometimes for more regulation and controls over production practices, including animal welfare. Against this background, the European Commission's midterm review of Agenda 2000 proposed a set of reforms that include further decoupling, continuing set-asides, and more cross- 
compliance rules with statutory environmental, food safety, and animal health and welfare standards.

Current EU compensatory payments still influence farmers' decisions on how much land to plant. This results not only because farmers are obligated to produce cereals on the base acres to receive the payments, but also because area payments in the European Union are made on an aggregate, fixed-area basis that is set at the national or regional level. Individual farmers do not have a base area-just eligible acres for which they receive payments and have area set-asides. If the regional base area is exceeded, the per-unit subsidy is prorated downwards proportionately for all farmers.

Because the prorating occurs on the total area planted ex post, farmers have an incentive to overplant in order to maximize their share of fixed budget outlays or to defend against share erosion due to overplanting by other producers. This means that the area payments are fully coupled to plantings because individual farmers are not penalized for their own decisions to overplant. Area payments with a national base area are therefore not a limit on total acres planted.

For EU cattle, the headage payments under "production limiting" arrangements are anything but production limiting because farmers are allowed to keep more cattle than are eligible for payments, so there is no absolute production control, and the number of eligible animals is not limited to the number on farms prior to the introduction of payments in 1992. Where numbers of animals are below the maximum that could be claimed per farm, farmers have an incentive to expand their stock up to the limits on which payments are made. Thus incentives in the program have been to encourage initial expansion of animal numbers and then to lock production in at around the levels that are consistent with the maximum number of animals eligible for payments. Those numbers reflect the very high levels of support for several decades as well as the incentives inherent in the headage payments.

The CAP reform of June 2003 requires decoupling at least 75 percent of payments in the arable sector and at least 50 percent in the beef and sheep sectors. Dairy premia will be added into the single farm payment after 2007. The decoupled single farm payment will be based on average payments claimed over the three-year reference period, 2000-02, and will be paid per eligible hectare of land. Entitlements can be sold with or without land. Member states are offered some flexibility in what year they begin, in fully or partially decoupling within the limits for each sector, giving 10 percent of the payments for environmentally friendly farming, and restricting entitlement trading within a region. All payments are to be reduced 3 percent in 2005, 4 percent in 2006, and 5 percent in 2007. Support prices will also decline. Payments will be conditional on compliance with various measures, including environmental and acreage set-asides.

Under the Luxembourg Council's decision of April 22, 2004 (based on the September 2003 proposal), a major reinstrumentation of the EU cotton and tobacco (along with olive oil and hops) programs will take place in 2006. In the cotton sector, an estimated 
$€ 700$ million is expected to fund two support measures, with $65 \%$ of the support taking the form of a single decoupled payment and the remaining 35\% taking the form of an area payment (European Commission 2003). Eligibility for the decoupled payment will be limited to growers who produced cotton during the three year period 1999-2001. The area payment will be given for a maximum area of 380,000 hectares in Greece, 85,000 hectares in Spain, and 360 hectares in Portugal and will be proportionately reduced if claims exceed the maximum area allocated to each country. To receive decoupled payments, cotton growers must keep the land in good agricultural use. To receive area payments they must plant (not necessarily produce) cotton.

Decoupling in the tobacco sector will be carried out gradually over a four year transition period, starting in 2006. In these four years, at least 40 percent of the tobacco support have to be included in the de-coupled single payment for farmers. Member states may decide to retain up to 60 percent as a coupled payment. The coupled payment may be reserved for producers for growers producing varieties of a certain quality. After 2010, tobacco aid will be completely decoupled from production decisions. Half of the transfers will take the form of a single farm payment while the remaining will be used for restructuring programs under the rural development policy. In principle, decoupled payments will be guaranteed to eligible producers until 2013. To receive decoupled payments, tobacco growers should maintain their land in good condition and comply with the standards on public health, animal and plant health, the environment and animal welfare (cross-compliance).

\section{Decoupling Efforts in Mexico}

About a quarter of Mexico's population depends on agriculture, which contributes 5 percent to GDP, down from 9 percent two decades ago. According to the OECD, total transfers to agriculture averaged $\$ 7$ billion annually during 1999-2001, $\$ 5.7$ billion of which went to producer support. This support corresponds to $\$ 1,000$ per full-time farmer equivalent and $\$ 53$ per hectare, both considerably lower than the OECD averages of $\$ 11,000$ per farmer and $\$ 192$ per hectare. About 29 percent of producer support went to maize, 21 percent to milk, and 13 percent to sugar.

Traditionally, Mexico's state agricultural enterprise, CONASUPO (Compania Nacional de Subsistencias Populares), has been heavily involved in the marketing, transportation, storage, and processing of most agricultural commodities. Maize, beans, and wheat, by far the most important agricultural commodities, have been heavily subsidized through a system of guaranteed prices. The government also set prices, which were usually announced before planting decisions were made and were uniform across the country and across seasons. CONASUPO bought unlimited quantities at the guaranteed prices. Hence, producers knew in advance the price they would receive and shifted production to crops with the highest degree of relative protection rather than with the highest profitability according to world prices. The poorest peasants did not benefit from 
guaranteed prices since they formally marketed little or none of their production.

In 1994, Mexico introduced PROCAMPO, a decoupled support program to provide income support to grain and oilseed producers - about 90 percent of all Mexican farmers. PROCAMPO replaced the old scheme of guaranteed prices. By supporting farmers' incomes rather than production of specific commodities, PROCAMPO was expected to make production and trade less distorted. PROCAMPO is also distributionally more attractive than the earlier guaranteed price program because poor subsistence farmers are eligible for payments and there is a ceiling of 100 hectares on the amount of land that a single farmer can use to claim payments.

Government credibility became a major issue for PROCAMPO. Initially, some producers did not believe that the government would actually implement the program. Fearing increased taxation, they underreported land allocated to eligible commodities. The government's turnaround, requiring that land be allocated to eligible crops after initially delinking payments from the current use of land, likely further discredited the government. (In 1996 the government increased the number of eligible crops.) The macroeconomic environment also played an important role. When PROCAMPO was in the design phase, most commodities were highly protected, but the 1994 devaluation of the peso sharply reduced protection rates.

Despite these shortcomings the program has at least two features that improve income distribution (sometimes at the cost of more inefficiency). First, decoupled area payments are given for the minimum of 1 hectare, even if the actual size of a farm is less than 1 hectare. Second, land reforms allow small farms to rent out approximately 10 percent of their land to larger farmers. These features can have a significant positive impact on income distribution compared with historical guaranteed prices. Few small farmers benefited from that system because they were often net buyers, sold products at distress prices at harvest, or could not take advantage of price supports because they where not integrated with market price centers because of high transaction costs (Sadoulet et al. 2001).

Just as the United States did, however, Mexico reintroduced its price support in 2002. New countercyclical payments, similar to those that the United States introduced in its 2002 Farm Bill, took effect with the 2002/03 marketing year. The payments were to equal the difference between the target price and the sum of the market price and PROCAMPO payments. The payments would apply to eight commodities. In addition, a new common subsidized price for electricity used for agricultural production was introduced (estimated to cost $\$ 0.6$ billion annually).

The most visible change in Mexican agricultural policies has been the move from support based on input use to support based on historical entitlements, under PROCAMPO (table 16). Border measures are still the dominant component of support, accounting for 64 percent of producer support during 1999-2001.

Mexico's decoupled payment program encountered several problems. The pro- 
gram was announced well in advance of the registration of eligible producers. The lag allowed many farmers to increase the amount of land in production of the eligible commodities and thus to increase their future payments. So rather than moving resources to more efficient uses, the scheme, initially at least, moved more resources into production that was already inefficient. Moreover, because land rights among landowners, tenants, and sharecroppers were unclear, it was difficult to determine who was entitled to payment.

The cost of PROCAMPO was also an issue and there were concerns that the government may have to cut back on other essential programs. The World Bank (1994), while supportive to the program, argued that there should be found ways to contain the overall PROCAMPO costs. ${ }^{20} \mathrm{In}$ fact, the report recommended that either the area payment should be reduced between 10-30 percent or the government should buy producer payments at a steep discount thus lowering the present value of the stream of payments over the lifetime of the program.

\section{Decoupling Efforts in Turkey}

The agricultural sector in Turkey employs 43 percent of the labor force and contributes 16 percent to GDP, down from 26 percent in 1980. Total agricultural support in Turkey reached an annual average of $\$ 9.7$ billion during 1999-2001, $\$ 6.5$ billion of it in direct producer support, according to the OECD (table 17) Of that amount, $\$ 5.1$ billion was transferred through border measures, the dominant component of agricultural support in Turkey. At 5.1 percent of GDP Turkey has the highest agricultural support rate among OECD countries and almost four times the OECD average of 1.3 percent. This support corresponds to $\$ 162$ per hectare, compared with $\$ 192$ per hectare average for OECD. Sugar accounts for 13 percent of estimated producer support, milk for 11 percent, and wheat for 10 percent. The main policy instruments for agricultural support have been border measures, administered prices, input subsidies, and budgetary payments. With a per capita GDP of a little over $\$ 3,000$, this support imposes considerable budgetary strains on the economy.

Responding to the high cost of support and its distortionary effects, Turkey embarked on a major agricultural policy reform program in 2001 with World Bank (2001a) assistance. A main component of the reform was to replace administered prices and input subsidies with annual direct income support payments. In addition, farmers were granted a one-time transition payment to cover the cost of transition from overproduced and highly subsidized commodities to other commodities.

Income support payments were set at the equivalent of $\$ 100$ per hectare, but even this low level of transfer implied an eventual annual expenditure of $\$ 1.9$ billion. The upper limit, initially set at 20 hectares, was raised to 50 hectares in 2002. As in Mexico, to allow small subsistence farmers (who otherwise received no support) to benefit from the program, a minimum payment was set for farmers cultivating below a certain threshold. 
A number of hard choices had to be made following the decision to implement direct income support payments. A key decision related to records (as was the case in Mexico). A pilot program was set up in several districts in four provinces to test two methods of developing a registry for producers. One method, applied in two provinces, used the existing land registry records. A second method, applied in the other two provinces, was based on certifications by the chief of the village, the council, and the local farmers associations. Payments were made on a per hectare basis in two installments for up to 2 hectares.

While the pilot benefited almost 10,000 farmers including many small operators, at a cost of $\$ 2.3$ million, numerous problems were encountered during implementation. Land registries contained unclear descriptions, shared titles did not specify the amount of land that each person owned, and many landowners who had inherited their land did not possess deeds. Registration procedures were also unclear, and various "producer certificates" were issued without uniform standards. There were many cases of sharecroppers declared ineligible for participation because they lacked official documents. There were also cases of false claims, for nonfarm land or land not in agricultural use.

Other problems were related to the design and implementation of the pilot. Farmers received inadequate information about the program, and consequently many failed to apply for benefits (especially in remote villages). The agencies involved in the pilot also received inadequate training and information. And farmers were not given enough time to apply for the program.

Although it is still too early to have a detailed assessment of the reform process, a preliminary evaluation is offered in a recent World Bank (2004b) review. DIS payments reached an estimated total of $\$ 1.25$ billion during 2002 and compensated about half of the 16 percent decline in farm income associated with the agricultural reforms (equivalent to $\$ 2.7$ billion). According to the same report, DIS payments reached about 90 percent of eligible producers. The reason that not all eligible producers received the decoupled payments was persistent communication problems (on many occasion farmers either did not know or when they knew, they thought that they were not eligible for support). Following the reforms, there was a clear shift from grains to sunflower, fruits and vegetables. The greatest beneficiary to the reforms have been the consumers whose burden was reduced by an estimated $\$ 3.6$ billion between 1999 and 2001. Poor have undoubtedly benefited even more, given that a large share of income is spent on food. ${ }^{21}$

\section{Experience with Buyouts ${ }^{22}$}

\section{The 1984 New Zealand Exit Grant}

Before 1984, New Zealand's farmers were receiving generous support-in some years as high as 40 percent of the value of production. In 1984, the government abolished the subsidies. With the economy almost on the brink of bankruptcy and facing deteriorating ex- 
ternal markets, inflation, and historically high interest rates, the government eliminated almost 30 different production subsidies. Although the end of agricultural subsidies took place in conjunction with overall deregulation of the economy and reduced input costs, currency appreciation and low commodity prices during 1985-87 made the transition stressful.

To ease the transition, the government provided one-time exit grants to farmers leaving the land, equivalent to about 66 percent of their previous annual income. Farmers with extremely low incomes were temporarily entitled to social welfare income support. Farmers were also offered limited financial advice. There was no substantive effort to soften the effects of the change. However, despite early predictions that large numbers of farmers would leave the land, only 1 percent of farms failed, with significant adjustments occurring in the form of off-farm employment and changes in input use and output mix.

Land prices, which had been kept artificially high by the subsidies, plummeted with their removal. Marginal land reverted to forest, and subsidy-driven land management problems ended. Now farmland values have more than recovered as farm profitability has been restored. Farmers reduced costs and focused on producing higher value products, where profitable. Many farmers restructured their debts and continued farming, adjusting farm practices to reduce input costs. With investment decisions now subject to commercial and good farming disciplines, agricultural input suppliers were forced to become more competitive, also improving the competitiveness of the agricultural sector.

Since 1986-87 the value of economic activity in New Zealand's farm sector has grown by more than 40 percent in constant dollar terms, and agriculture's contribution to the economy has risen from 14.2 percent of GDP in 1986/87 to 16 percent in 1990/2000. With the removal of farm subsidies, growth went from 1 percent in 1986 to the current annual average of 5.9 percent. New Zealand has around 80,000 farm holdings. Sheep and beef farms account for 20 percent of the number of farms and dairy farms for 18 percent. Horticulture, forestry, cropping, and rural tourism also contribute to its rural sector, which employs 11.4 percent of the workforce. About 80 percent of New Zealand's farm outputs are exported, accounting for more than half of New Zealand's merchandise exports.

\section{The 1995 Canada Railway Subsidy ("Crow Rate") Buyout}

Canada's Crow Rate program (named for Crowsnest Pass in the Rocky Mountains) goes back to 1897, when Canadian Pacific Railway was given a subsidy of $\$ 3.4$ million to build a line between Alberta and British Columbia. In exchange for the subsidy, Canadian Pacific agreed to charge grain farmers 20 percent less than the (then) prevailing rates. The 1925 Railway Act made the subsidized rates statutory. Over the years the Crow subsidies were extended to numerous commodities. Because of the higher prices received by Western grain farmers due to the transport subsidies, value added industries (especially live- 
stock production), moved to Central and Eastern Canada because of lower grain prices (Klein and Kerr 1995).

In 1995 the Canadian government decided to terminate the program, which was becoming fiscally unsustainable. To ease the transition, a one-time payment of $\mathrm{C} \$ 1.6$ billion was made to eligible farmers. An additional $\mathrm{C} \$ 300$ million was invested in a more efficient grain handling and transport system. The one-time payment was spread over two fiscal years and made to owners of prairie farmland with eligible crop grown in 1994 and summer fallow land in 1993, adjusted for a productivity factor, distance factor, and provincial allocation factor. Eligible crops were those that were eligible for subsidies under the Western Grains Transportation program. There were no restrictions on how the payments were used, and they were treated as a capital gain rather than as current income, a concession valued by the OECD at an estimated $\$ 0.6$ billion.

The outcome has been positive overall. The lower grain prices lifted a constraint on value-added industries, encouraging entrepreneurship and innovation, led to diversification into specialty crops, lowered land prices, and exposed the industry to trade challenges. The change also brought Canada into compliance with international trade agreements.

\section{The 2002 U.S. Peanut Quota Buyout}

The U.S. peanut program goes back to 1934, when peanut producers agreed to reduce their acreage in return for payments. The program failed to reduce output and was revised in 1941 by introducing individual acreage allotments and penalties for farmers who exceeded the allotments. The allotments were not enforced, however. The Agricultural Act of 1949 established support prices for peanuts, and until 1978 all peanuts from approved allotments were guaranteed the support price. The program again ran into financial difficulties primarily because of the introduction of high-yielding varieties. Beginning in 1978, peanut quotas were set annually and producers received support for quota peanuts only. During 1979-82 farmers had to have both quantity and acreage allotments to be eligible for payments. The acreage allotment was abandoned in 1982. Quantity quotas were tradable, with some exceptions. Imports were banned.

The program again ran into trouble as the costs of the program grew enormously. Peanut manufacturers pressed for reforms because they wanted access to lower priced peanuts, while the introduction of NAFTA allowed peanut products to enter duty free from Mexico and Canada.

There were some modifications in 1996, but the biggest change came with the 2002 Farm Bill, with the government deciding to buy out the marketing quotas created in 1978 (Chvosta et al. 2003). Eligible quota holders are to be compensated for the lost value of the marketing quota during fiscal years 2002-06. Quota holders can elect to receive payment in five equal installments of $\$ 0.11$ a pound per year times the actual quota allotment for the 2001 marketing year or to receive the undiscounted sum of all the payments in the 
first year, equal to $\$ 0.55$ a pound. Given that an average effective quota for 1998-2000 is 5.6 million tons, the buyout is expected to cost $\$ 181$ million a year or $\$ 1.4$ billion for the five-year period. During the same period, the annual value of U.S. peanut production was $\$ 3.1$ billion (8.79 million tons times $\$ 355$ per ton). In addition to the quota buyout, peanut producers will be compensated by receiving support from the other provisions of the 2002 Farm Bill (decoupled and countercyclical payments).

Several factors led to this change in the existing program, including pressure from NAFTA, opposition industry groups, and enormous increases in the fiscal costs of the program.

\section{The 2004 U.S. Tobacco Quota Buyout}

The most recent buyout is the US tobacco marketing quota program. Under the legislation, payments will be made to tobacco quota owners and producers - as of 2002 there were 57,000 tobacco producers and 360,000 absentee quota owners. ${ }^{23}$ The buyout ends the Federal tobacco marketing quota system and price support loan programs, which were introduced in 1938 and took various forms in later legislations. Following the buyout, there will be no geographical, acreage, or marketing restrictions of tobacco. In principle, anyone can produce tobacco and market it to any buyer at any time (USDA 2004).

Quota owners will receive \$7 per pound of quota owned based on the level of basic quota of the 2002 marketing year. Payments will be made in 10 equal annual installments, i.e. $\$ 0.70$ per pound per year. They will begin in 2005 and end in 2014 . Farmers who produced tobacco during 2002-04 will be eligible for an additional \$3 per pound (those who produced one or two years out of the 3-year period will receive prorated amounts of $\$ 1$ or $\$ 2$ per pound). Although there are no provisions to authorize up front payment for the entire buyout (as was the case with the peanut buyout), there are provisions that assign financial institutions to receive the rights for the payments and in turn give tobacco quota owners and producers a discounted lump-sum payment.

The funds required to finance the buyout will be obtained through assessments on manufacturers and importers of all tobacco products sold in the US. It is estimated that the program will cost an estimated $\$ 10.14$ billion over the 10 -year period, implying an average annual transfer of $\$ 2,430$ per tobacco quota owner (including growers).

In a sense, the tobacco buyout may be viewed as a radical reform initiative. However, such assessment must be made against the relevant background. Given that the quotas were not binding (i.e., US consumption of domestically produced tobacco at world prices was substantially smaller than the sum of quotas, hence quota owners did not use them), the buyout appears to have been a very expensive policy choice. ${ }^{24}$ Lastly, it should be mentioned that the buyout found, at least implicitly, political support because of the public's awareness and sensitivity to the negative health effects of smoking as well as the high treatment costs of smoking-related illnesses. 


\section{ASSESSING DECOUPLING}

Total direct support to agricultural producers as measured by the producer support estimate has remained fairly constant over time, averaging $\$ 235$ billion in 2000-02 with most support concentrated in a few sectors (milk, meats, and rice). But the share of border support has declined to 63 percent as taxpayer-financed subsidies paid directly to farmers have increased significantly. From 1986-88 to 2000-02, domestic subsidies to farmers rose 60 percent, with large impact programs (output and input subsidies) increasing moderately compared with the substantial increases in so-called smaller impact programs (subsidies for land area and number of animals, decoupled historical entitlements, and payments based on input use restrictions and overall farm income). Payments based on area planted or number of animals has increased the most, followed by historical entitlements. However, several countries have made little progress in reforming the composition of support away from border support to domestic support (Japan, Korea), while others have not needed substantial reforms (many members of the CAIRNS Group).

The move toward decoupled agricultural policies is undeniably a step in the right direction in reducing trade distortions and increasing world prices for developing countries exports. But the reforms have been slow and decoupled type payments are concentrated mostly in the grains and oilseeds sectors. As for reductions in trade distortions, experience in the decoupled programs described above has been mixed. The degree of decoupling is a continuum, with payments based on land constraints or input use, historical entitlements or on individual characteristics not related to farming being considered far less distorting than the traditional measures of border protection and direct input and production subsidies. But there is no fully decoupled agricultural support measure in theory or in practice. But the reality is more complex, not only in the economic impacts of decoupled payments on producer behavior but also the characteristics of the programs themselves in their implementation. The few countries studied in detail here have moved away from border support to domestic support and to less distorting domestic support. Although there is evidence of a reallocation of resources across agriculture as a result, the decline in total output and increase in world prices have been modest. In addition to the uneven distribution of "coupled" subsidies (less in major field crops, more in sugar and livestock), other factors help to explain the lack of significant reductions in output. Even if farmers cannot influence a payment, the payment can influence their production decisions, thereby limiting their effectiveness in reducing trade distortions.

There are several mechanisms for how payments influence output, even though they are not linked to current farm-level production. Payments, especially if they are large, can reduce farmers' aversion to risk through the 'wealth effect'. Depending on how payments are disbursed, the variability of farm income can also be reduced, thereby reducing risk facing farmers that leads to increased output (the 'insurance effect'). As noted 
by OECD (2003b, 2004), a number of studies have concluded that risk effects can be as large as coupled subsidies in enhancing output study, while the OECD's own analysis finds risk reduction effects to be less than a fully coupled subsidy. Another mechanism by which decoupled payments can affect farmers' investment and exit decisions is through relaxing constraints facing them in capital and labor markets (OECD 2003a). Direct payments allow banks to make loans that they otherwise would not and allow farmers with specialized skills to stay in agriculture. Studies by the USDA (2003) and Roe et al. (2004) find the production effects to be minimal while Vercammen (2003) finds they can be as large as a coupled production subsidy. Direct payments also help cover fixed costs, allowing farmers to cross-subsidize production at market prices (Chau and de Gorter 2002). Finally, eligibility rules have changed, and expectations about future policies and dynamic considerations affect current production decisions because producers develop expectations about future assistance based on past government actions (see recent WTO Panel Report ruling on US cotton subsidy programs).

So the experience is that perfectly designed decoupled payments can distort trade which can be exacerbated if decoupled programs are implemented imperfectly. The primary motivation for decoupling is to compensate farmers for the move to free markets by providing transitional adjustment assistance. This also makes the programs politically more palatable and transparent. Ideally, compensation programs would be universal (open to all sectors in the economy, not just agriculture) or at least non-sector specific within agriculture. A simple and minimally distorting scheme would be a one-time unconditional payment to everyone engaged in farming or deemed in need of compensation that is nontransferable, along the lines of the one-time buyouts discussed earlier.

However, because a one-time buyout is an unlikely outcome (unless it is welltargeted in one sector), specific attention should be given to time limits, harmonization with other support programs, government credibility, and constraints on input use. Unless these aspects are properly addressed, decoupled programs are likely to have the same detrimental effects as other subsidy programs.

Most important, programs should be strictly limited in duration. The European Union and Turkey have no limit: the United States had (at least implicitly) one in the 1996 Farm Bill but violated it three years later. Mexico's reform had a time limit, which so far has not been extended. A time limit helps to ensure that payments are made for adjustment purposes only.

If there are other (coupled) support programs, the decoupled program may not eliminate the incentives to overproduce. All four decoupling cases examined here either left other coupled support programs in place or added new ones.

To maintain government credibility and reduce uncertainty, eligibility rules need to be clearly defined and not allowed to change. The time period on which payments are based, the level of payments and the sectors covered should all remain fixed. Updating bases and adding crops create a government credibility problem, making the decoupling 
policy time inconsistent. If governments have the discretion to change eligibility criteria and payments as market conditions change, these commitments will not be viewed as binding. Farmers, meanwhile, will change their production decisions to reflect this, thus undermining decoupling.

Support to specific sectors within agriculture should be in the form of taxpayerfunded payments. There should be no requirement of production. Land, labor, and any other input should not have to be in "agricultural use."

Experience shows the difficulty of designing effective decoupling schemes. But strict criteria are required to minimize direct trade distortions because sector-specific decoupled support can still affect output indirectly, through wealth effects and lessened constraints in credit and labor markets. One way to improve the performance of decoupling schemes might be to have the WTO specify the conditions. 


\section{ENDNOTES}

1 The previous seven GATT rounds-Geneva (1947), Annecy (1949), Torquay (1950-51), Geneva (1955-56), Dillon (1961-62), Kennedy (1963-67), and Tokyo (1973-79) - did not deal with the issue of agricultural support although the latter two dealt with the related issue of price stabilization mechanisms through international commodity agreements.

2 Throughout the paper the terms domestic support, budgetary support, and domestic measures are used interchangeably and imply taxpayer-financed support. The terms border support, border measures, and market price support are also used interchangeably and imply consumer-financed support. When necessary, explicit mention to export subsidies is made, which are typically considered a border measure, but also involve taxpayer financing.

3 Studies which have looked at various aspects of the capitalization of subsidies into land values include Huffaker and Gardner (1986), Johnson and Short (1983), Phipps (1982), and Traill (1982). A volume of the American Journal of Agricultural Economics [85(3), August 2003, pp. 744-773] published five papers on "Agricultural Land Values, Government Payments, and Production" (Goodwin, Mishra, and Ortalo-Magnè; Lence and Mishra; Roberts, Kirwan, and Hopkins; Phipps; and Turvey).

${ }^{4}$ For example, one may well argue that export subsidies should have been integrated into the market access pillar; or, for that matter into domestic support since in most cases they have the same effect as price support.

5 WTO's box classification draws from the traffic light analogy: green (permitted), amber (slow down, reduced), red (forbidden). The URRA has no red box because support above amber box is prohibited.

6 An ideal measure of border protection would resemble the following formula $\left(P_{t}^{\text {domestic }}-P_{t} t^{\text {world }}\right) * Q_{t} t^{\text {produced }}$.

7 In addition to the measurement problem, there is a conceptual problem with the AMS. Border measures were supposed to be disciplined within the "market access" and "export subsidies" pillars of agricultural support. However, they are counted as part of the "domestic support" pillar.

8 Prior to Swerling's proposal, Brandow (1955) and Black (1958) had proposed a major overhaul of US agricultural policies.

9 Swerling (1959) noted that the reason the US Congress did not include farming in the social security legislation of 1935 was because of various administrative complexities. However, by 1955 there was a comprehensive administrative machinery in place, including a system of income reporting upon which a social insurance plan for the farm sector could be built and hence there was no need to treat agriculture any differently than any other sector of the economy.

10 A detailed list of all the European decoupling proposals can be found in Little et al. (2004).

11 Nash's reference to the cotton industry is not clear. Most likely, it refers to the 1959-61 change in the US cotton program whereby producers were offered higher support prices in exchange for lowering the acreage on which support was based (Cochrane and Ryan 1976) [Bruce Gardner brought this explanation to our attention].

12 The bond scheme proposal for CAP was first proposed by Tangermann (1991) and later by Beard and Swinbank (2001) and Swinbank and Tangermann (2001). Most of the 'bond scheme' work has been published in a volume edited by Swinbank and Tranter (2004).

13 The United States is world's second largest cotton producer after China, accounting for 17 percent of global production and 35 percent of global exports. During the period under consideration by the WTO 
panel (1999-2002), Brazil consumed most of its cotton production (about 0.8 million tons).

14 A decoupled tax - a tax that does not effect consumption or labor supply decisions - is even more difficult to design and implement. Ideally, it would be a tax whereby each taxpayer pays an amount (the same every year, regardless of income) that is based on tax payments of earlier years, which is close to a poll tax.

15 The non-zero social opportunity costs to finance agricultural support have been studied by Wallace (1962) and Gardner (1983).

16 Baffes and Meerman (1998), in underscoring the expensive nature of decoupled programs as one of their shortcomings, recommended countercyclical payments (based on historical area and a current commodity price index) as a policy alternative to fixed decoupled payments.

17 For a review of the earlier decoupling attempts in the US, EU, and Canada see Gilson (1988).

18 The reform, known as the McSharry reform after the EU's Commissioner for Agriculture, together with the Blair House Accord of the United States, paved the way for the signing of the Uruguay Round Agreement on Agriculture in 1994.

19 The origins to the European Union go back to 1950 when the French Foreign Minister Robert Schuman proposed integrating the coal and steel industries of Western Europe. As a result the European Coal and Steel Community (ECSC) was set up in 1951 consisting of Belgium, West Germany, Luxembourg, France, Italy, and the Netherlands. Following the success of the Steel Community, these countries signed the Treaties of Rome in 1957, creating the European Atomic Energy Community (EURATOM) and the European Economic Community (EEC). Subsequently, the member states removed trade barriers and formed a "common market" and in 1967 the three Communities were merged. The European Union has grown in size following successive waves of accessions. Denmark, Ireland and the United Kingdom joined in 1973 followed by Greece in 1981, Spain and Portugal in 1986 and Austria, Finland and Sweden in 1995. Ten more countries joined in 2004: Cyprus, the Czech Republic, Estonia, Hungary, Latvia, Lithuania, Malta, Poland, Slovakia and Slovenia. Bulgaria and Romania are expected to follow in a few years while Turkey is currently contemplating formal candidacy status (http://europa.eu.int).

${ }^{20}$ The World Bank (1996) played an instrumental role the agricultural sector reforms in Mexico and supported the process by two adjustment operations, $\$ 300$ and $\$ 400$ million. PROCAMPO fulfilled one of the second agricultural adjustment operation's conditionality.

${ }^{21}$ Although decoupled programs are supposed to facilitate the transition from existing distortionary programs to a market-based sector, their success (or failure for that matter) is linked to their properties as poverty reductions mechanisms, as exemplified by the cases of Mexico and Turkey. However, while decoupled mechanisms may have attractive poverty reduction features, there might be other programs which can deal with poverty in a much more effective way. For a comparison between decoupled programs and povertybased payments see Castañeda (2004).

22 Orden et al. (1999), who have looked at a number of buyout attempts in US agriculture, make a distinction among the following alternative reform strategies: cash outs (slow, compensated transformation of programs), buy outs (quick, compensated termination of programs), squeeze outs (slow uncompensated diminution of programs), and cutouts (uncompensated elimination of programs).

${ }^{23}$ The tobacco buyout, formally known as the Fair and Equitable Tobacco Reform, was part of the American Jobs Creation Act of 2004. It was approved by the US Congress on October 11, 2004 and signed into law by President Bush on October 22, 2004.

${ }^{24}$ The generosity of the tobacco buyout is apparently related to the fact that it was signed into law less than two weeks prior to the presidential elections of November 2, 2004. 


\section{Box 1: The Political Rhetoric of Agricultural Support}

The level of agricultural support has been subject to political rhetoric with the popular press frequently citing the 'one billion dollar per day' subsidies given to the agricultural sectors of rich countries. Quite often this figure is compared to the GDP of developing countries or to the total aid received by poor African countries. In fact, the OECD's total support estimate peaked at $\$ 357$ billion in 1999, $\$ 8$ billion short of the $\$ 365$ billion required to make the argument technically accurate. However, it is clear from the definitions of various measures of support given earlier, that some adjustments must be made in order to make that figure a proper measure of support. A considerable part of the total support estimate is general support services such as research and development, funding for agricultural schools, and inspection services. Transfers of this nature, however, take place in virtually every country and every sector of the economy, not just in the agricultural sectors of OECD countries. A more accurate measure of protection would be the Producer Support Estimate, which accounts for $\$ 680$ million per day.

The rhetoric on agricultural protection has its humorous side too. The Chairman of Unilever Niall FitzGerald in a speech given on January 16, 2002 in London, remarked that “... each cow within the European Union is subsidized to the extent of a $\$ 1$ a day!" This is the first explicit mention - to the best of the authors' knowledge- of the association between the support given to the European milk and beef industries and the number of cattle raised in Europe. This association was later popularized by the British Prime Minister Tony Blair in a speech given on February 7, 2002 in Abuja, Nigeria. In fact, Blair misquoted FitzGerald by stating: "As Unilever Chairman Niall FitzGerald has commented, every cow in the European Union is subsidized to the tune of $\$ 2$ a day."

Foreign Policy (2003, p. 31) commented on the subject of cow subsidies as well by noting that "... the average cow in Switzerland earns the annual equivalent of more than $\$ 1,500$ in subsidies." The cows found their way to the United Nation's flagship publication. The 2003 Human Development Report noted that OECD per unit subsidies for cows and cotton bolls are considerably higher than OECD per capita aid for Sub-Saharan Africa. In an accompanying chart (p. 155), entitled Cows and cotton receive more aid than people, the report compared the $\$ 2,700$ and $\$ 913$ per cow annual subsidies in Japan and the European Union with the $\$ 490$ per capita income in Sub-Saharan Africa. Note that the United Nation's figure for the European Union implies a transfer of $\$ 2.50$ per day per cow, even higher than British Prime Minister's $\$ 2$ figure, which was already twice the figure quoted by the Chairman of Unilever.

How much support do the European cows actually receive? The combined annual producer support to the European Union's beef and milk industries during 1999 was estimated at $\$ 40$ billion according to OECD. Dividing $\$ 40$ billion by the number of cattle raised in the European Union (approximately 82 million) gives $\$ 487$, consistent with an implicit transfer of $\$ 1.33$ per day to each unit of cattle. Note that this calculation accounts for all units of cattle (both meat and milk producing), not just cows - similar to per capita income calculations which are based on the entire population not just heads of households or mothers. 


\section{Box 2: Early Decoupling Proposals in the United States and Europe}

Decoupling was discussed in the academic literature as early as 1945, when the American Farm Economic Association announced 18 Farm Price Policy Awards for the best papers on "a price policy for agriculture, consistent with economic progress, that will promote adequate and more stable income from farming." Nicholls and Johnson (1946) - recipients of the first- and second-place awards-summarized the main findings of the 18 award-wining papers. Several recommendations closely resembled decoupled support. For example (p. 281): “Cochran presents a special formula for progressively smaller income payments for aiding producers in adjusting their operations from a support level to a free market situation. These declining payments would be based on production during 1939-41, so that the producer would not be 'tied to commodity in surplus to receive a payment benefit.' Thus, he could shift to some other product during the payment period without losing the specified payments."

More than a decade later, Swerling (1959) advocated decoupled support in the United States. Specifically, he argued that the price stimulus should be replaced by an income-insurance plan for farmoperators that would include the following elements:

- benefits will be related to the income experience of the particular individual during the recent past;

- the purpose of the payments would not be to support income at artificially high levels but to prevent a severe temporary decline in individual income;

- the right to benefits would be attached to the person, not to farm land or the farm enterprise, and would accordingly not be transferable not even to their successors;

- the benefit to be enjoyed by any individual would not exceed a modest maximum; and

- benefits would not be conditioned upon the production of particular commodities or even upon continued employment in agriculture.

Nash and Attwood (1961) also argued that price support in the United Kingdom should be removed. Furthermore, if after the removal of such support producers are left with incomes which are judged to fall short of their due reward, then these incomes can be supplemented with decoupled cash transfers. Essential requirements for these transfers were to be:

- not be related to future output or be allowed in any way to influence future productive decisions;

- not affect the choice of any individual whether to remain in agriculture or to enter an alternative occupation;

- participation should be limited to those now engaged in agriculture; and

- the cash transfers should have a fixed term.

Uri (1970) also argued that price support in Europe must be substituted by income support; he proposed four essential rules:

- compensation for lower prices should be based on average yields of the entire European Community;

- payments should be fixed on the area under cultivation in the years preceding the decision to lower prices;

- there should be minimum and maximum time periods and would limit the subsidy to the farm operator, so that it would not be passed to successors; and

- $\quad$ payments should vary inversely with the size of farms. 


\section{Box 3: The Minister's View of Decoupling}

The debate on decoupling typically reflects discussions within the ministries of agriculture and trade. Actual implementation of decoupled support programs, however, depends crucially on decisions made by the ministry of finance, especially when increases in taxpayer funds are required. The following narrative reflects the thinking of an agriculture minister and a finance minister on decoupling. Although the conversation is hypothetical, to a large degree it reflects arguments raised during discussions among senior officials between the two ministries, as experienced by the authors of the present paper.

AGRICUlture Minister: After all this noise in Seattle and the meetings in Doha and Cancun, I asked my research assistant to take a look at the cost of my agricultural commodity programs. He dutifully reported back to me last week and said that my commodity programs cost $\$ 330$ billion every single year, almost one billion dollars per day. My producers get $\$ 248$ billion; our consumers pay $\$ 160$ billion and your taxpayers pay $\$ 88$ billion. My assistant also said that most of this money does not even reach my farmers; and the little that does, goes mostly to corporate farms for a few commodities. Just a trickle for the family farm. He pointed out some other disturbing findings. My policies depress world commodity prices and displace our competitors who threaten to take us to the courts. Some of our poor friends are upset with my policies too. They do not get much out of what they sell because of low commodity prices caused by my commodity programs and it looks like they will come to you for more help.

FINANCE MINISTER: These are disturbing findings, indeed. In fact, this reminds me the story I was reading in the newspaper the other day that each of your cows gets $\$ 2$ per day in subsidies! But, anyway, how can I help you?

AGRICULTURE MINISTER: Then, I asked my other assistant to do some more research and find ways to fix the problem. She came up with a brilliant idea! She called it decoupling.

FINANCE MiNISTER: Decoupling? Hmm ... What is decoupling?

AGRICULTURE MiNISTER: Well, it's simple. Here is how it works. I will still support my producers. But, instead of guaranteeing them high prices by blocking imports with tariffs and quotas and giving them money based on how much they produce now, I will just give them a single payment each year which will be based on how much they produced three years ago. Since they will be receiving the same amount of support they receive now, I think they will like it. Why shouldn't they? They can do whatever they want with the money and they can go wherever they want since they would not have to produce any more. Only the ones who find it profitable will continue to produce. Because less will be produced, commodity prices will go up. And, if we can convince our friends to do the same, prices will go up even further. My farmers will require less support and this will keep our competitors happy. No more court threats, no more attorney's fees. Our poor friends will no longer ask you for aid.

FinANCE Minister: This is an excellent idea! But ... wait a minute. Let me get it straight. Are you telling me that you will put a program in place so in 100 years from now, people will receive payments simply because their grandmothers and great-grandfathers happened to produce cotton a century ago? Don't you think it is immoral and fiscally irresponsible to impose such a large burden to our grandchildren? Don't you realize the budgetary and sustainability implications of your assistant's idea?

AGRICULTURE MINISTER: In fact, this is not exactly what I had in mind. I plan to have the program in place for the next 15 years only; then I will discontinue it. That's it! No more tariffs, no more quotas, no more price support! Nothing! I also plan to reduce the payments each year gradually.

FINANCE MINISTER: Who will finance all this anyway?

(continued next page) 


\section{Box 3: The Minister's View of Decoupling (continued from previous page)}

AGRICUlTURE MiNISTER: Since you have already promised me $\$ 88$ billion from your taxpayers for the years to come, I am only asking for a fraction of the other $\$ 160$ billion that we have been collecting from our consumers every year. The reason I am asking for less money is because when I give support in a decoupled way, growers will produce less, commodity prices go up, and farmers will need less support. I will also make sure that most of the money goes to the family farms. No more support to corporate farms, input suppliers, and landowners. So, I am thinking that this year I will need an additional $\$ 80$ billion, only half of the $\$ 160$ billion I used to get. Next year $\$ 72$ billion. The year after only $\$ 64$ billion. After ten years, I will not even ask for the full $\$ 88$ billion that you have been giving me so kindly for so long.

FINANCE MINISTER: Don't you think you are a little unfair? I understand, you want to get rid of tariffs. You may have a point there. Tariffs can be nasty sometimes. Most of them have peaks, some are specific, many are seasonal, others come with quotas; there is tariff escalation too. Ok, I admit it. It's a mess out there. But you know what? At least, tariffs are paid by the ones who consume the product. And, let's face it. Consumers who buy these products have a choice of buying something else instead, or buy nothing at all and keep the money. And, I get to keep the tariff revenue too. Not a bad deal after all. Now, not only you want me to give up my tariff revenue but also you want me to go out there and collect an extra $\$ 80$ billion, basically taxing everybody indiscriminately without giving them any choice - if I gave them a choice, they would not pay taxes, anyway. How can I do that to my taxpayers?

AGRICUlTURE MiNISTER: But, high tariffs on specific commodities discriminate against those who need to buy the product. And, they distort both consumer's and producer's market. An income tax gives the consumer the choice to consume whatever product at market price-no discrimination between products. Besides, decoupling is a welfare enhancing policy mechanism ... it satisfies the principle of Pareto optimality ... furthermore, the triangular areas $\beta+\delta$ can be redistributed in such a way so that ...

FINANCE MINISTER: I understand. You must come up with something. It is this Seattle and Cancun thing. Look, if you really want to go ahead with a transition scheme, I have a better and simpler idea. Instead of flirting with decoupling, why don't you gradually reduce support for the next 15 years by a mere $\$ 16$ billion each year? By the end of your transition period, support will end. Why bother comparing triangles and rectangles with trapezoids? We have lived with support for almost a century, anyway. If you had begun reducing your support in 1986 when negotiations on your celebrated round on multilateral trade negotiations started, 2002 would be the last year of support and you would not even be here begging me for money. You should appreciate my advice. In fact it is not an advice. It is an offer. I give up my tariff revenue! 


\section{Box 4: Brazil vs. the United States}

On September 27, 2002 Brazil requested consultation with the United States regarding subsidies provided to US cotton producers (WTO 2002). On March 18, 2003, the Dispute Settlement Body of the WTO established a Panel, with standard terms of reference. On April 26, 2004 the WTO issued an interim ruling in favor of Brazil, which was upheld at the final ruling issued on September 8, 2004 (WTO 2004).

Brazil argued that the US cotton subsidies are inconsistent with various provisions of the Agreement on Subsidies and Countervailing Measures, the Agreement on Agriculture, and GATT 1994. In practical terms, the claim was that (i) during the four marketing years 1999-2002 the United States provided domestic support to cotton that was in excess of the support during the 1992 marketing year decided under the Peace clause of the Agreement on Agriculture and (ii) the export subsidies (i.e., export credit guarantees, step-2 payments) are in violation of the Agreement on Agriculture. Thus, US cotton subsidies "caused serious prejudice to the interests of Brazil" because of a "significant price depression and price suppression." Brazil supported its case by utilizing the econometric model developed by FAPRI showing that the United States subsidies induced a $41 \%$ increase in US cotton exports, hence reducing the world price of cotton by $12.6 \%$. According to these figures, the estimated injury suffered by Brazil was well in excess of $\$ 600$ million for the marketing year 2001 alone. Since the United States is in the process of appealing the ruling, the case is likely to take a few years before the US takes steps that satisfy Brazil. In case that the steps are not satisfactory, Brazil is likely to suspend equivalent concessions (i.e. retaliate through imposition of duties on US imports).

This is the first case to focus on agricultural subsidies in a North-South dimension. The ruling was issued against the background of the ongoing critical agriculture negotiations, the expiration of the Peace clause, the more assertive stance taken by the so called G-20 group as well as the Sectoral Initiative on Cotton (see Box 5). There are numerous implications (not necessarily mutually exclusive) for the WTO and the Doha Development Agenda as well as for the developing countries and international institutions:

- Because it is the first case of a developing country challenging an OECD farm subsidy program in WTO, it may set a precedent. And, if more cases like that follow, there may be a shift on the focus of WTO's activities from negotiation to litigation. The ruling also coincides with the expiration of the Peace clause (i.e. Article 13 of the Agreement on Agriculture) and thus may "open the floodgates" for other domestic subsidy cases.

- Because this dispute may be just the tip of the iceberg of potential upcoming cases, the way to avoid a significant increase in these disputes is to make significant progress in the Doha Development Agenda. Hence, the ruling may help agencies such as the EU Commission and the US Trade Representative's Office to confront domestic protectionist lobbies.

- The ruling strengthens the position of many developing countries regarding their claims that OECD subsidies depress world prices. Benin and Chad, two of the proponents of the Sectoral Initiative on Cotton, were involved in the Cotton proceedings as third parties.

- This dispute enhances the importance of models analyzing the effects of subsidies on world prices and export shares thus making authors (and their affiliations/institutions) more accountable regarding their analyses. The ruling also highlights the importance of current measures of support (such as OECD's Producer Support Estimate and WTO's Aggregate Measurement of Support) along with the interpretation of their various components (i.e. smaller versus large effect on production and trade). WTO's definition of "decoupled support" becomes important as do the definitions of decoupling used by the United States and the European Union. 


\section{Box 5: Sectoral Initiative in Favor of Cotton}

On April 31, 2003 four West African cotton producing countries (Benin, Burkina Faso, Chad, and Mali) submitted a joint proposal to the WTO and demanded that support given to the cotton sectors by the United States, China, and the European Union should be removed and, until full removal of the support takes place, these four cotton producing countries should be compensated accordingly. This move, often referred to as the "cotton initiative" was aided by IDEAS, a Geneva-based NGO funded by the Swiss government.

The four West Africa cotton producers argued that they lost an estimated \$250 million in export earnings during the 2001/02 marketing season due to cotton subsidies. When the indirect effects of these subsidies are considered, the injury reached $\$ 1$ billion, according to the proposal. Because the standard WTO remedies (compensation through supplementary concessions or imposition of countervailing duties) were not feasible alternatives for the concerned governments, the proposal called for "transitional measure in the form of financial compensation for cotton producing LDCs to offset the injury caused by support of production and export. Such financial compensation should be calculated in proportion to the subsidies granted by countries which support their cotton production. It will decrease (terminate) as and when the subsidies are reduced (abolished)." The proposal further argued that "When defining the total amount of compensation, the direct and indirect affects of support for cotton production of the economies of LDCs should be taken into account. The compensation should be sufficiently high to constitute additional incentive to decrease or phase out subsidies as soon as possible. The unit amount and the total amount of subsidies should be taken into account when dividing the compensation among countries which subsidize production." (WTO 2003, p. 7).

The cotton initiative received considerable attention during the Cancun Ministerial meetings and the issue was facilitated personally by the Director General of WTO, who urged ministers to consider the proposal seriously. Numerous countries were sympathetic to the initiative including Argentina, Australia, Bangladesh, Canada, Cameroon, Guinea, India, Senegal, and South Africa. Despite the sympathy, there were doubts whether it would be to the benefit of the Doha Development Agenda if a commodity was treated differently. Furthermore, it became apparent at an early stage that direct compensation, as envisaged by the concerned countries, was an unlikely outcome. The inability to deal effectively with the "cotton initiative" was part of the reason for the failure to reach agreement in Cancun.

In response, it was determined that while the trade part of the request (i.e. subsidies) fell within WTO's mandate, the development part of the request (i.e. compensation) should be handled by the multilateral institutions in coordination with the concerned governments. To that end, a WTO-sponsored conference took place on March 23-24, 2004, in Cotonou, Benin, where both bilateral and multilateral donors reaffirmed their willingness to deal with the development part of the cotton initiative, albeit within the existing channels. A follow up conference took place on July 4-5 in Paris, sponsored by the European Union.

On August 1, 2004, the WTO General Council reached a decision on the frameworks to proceed with multilateral trade negotiations. The General Council, which took notice of the Cotonou workshop of March 23-25, 2004, emphasized that the theme should be addressed "ambitiously, expeditiously, and specifically" and instructed the Director General to consult with the relevant international organizations, including the Bretton Woods Institutions, the Food and Agriculture Organization and the International Trade Center to direct effectively existing programs and any additional resources towards the development of the economies where cotton has vital importance. The WTO sponsored two rounds of consultations (October 22 and November 18, 2004) on the "Development Assistance Aspects of the Cotton Initiative" while on November 19, 2004 it established the Sub-Committee on Cotton. 


\section{Box 6: The Brannan Plan in the United States and the Mansholt Plan in Europe}

The Brannan Plan-named after the former US Secretary of Agriculture Charles F. Brannan-was proposed to the US Congress (both House and Senate Committees on Agriculture) on April 7, 1949 (Christenson 1959). The Brannan Plan, which burst like a bomb across the US farm policy scene, consisted of four main ideas: (i) An income standard to replace the old 1910-14 parity price standard; (ii) Production, or income payments, to support gross returns to producers of perishable commodities (price support programs would be continued for production of storable commodities). (iii) A new list of farm commodities (including the important animal products) to replace the old so-called basic commodity list; (iv) No price or income support on production above certain limit-that limit to be determined by the size of the typical farm.

The Brannan Plan was denounced by a number of Congressmen and farm organizations, including the American Farm Bureau Federation and eventually it was defeated in the US Congress. There were at least four causes behind the defeat of the Plan (Cochrane and Ryan 1976). First, it faced opposition by large commercial farmers who were well represented in Washington and were violently opposed to points (ii) and (iv). These farmers did not want to see their income subsidy in the form of production payments exposed to public view nor did they want any limit on support. Second, the Plan's cost was so high that it drove away its natural allies, including many economists and Congressmen who were sympathetic to the idea of direct income support. Third, the Republican party - the Plan was proposed under the Truman administration - was badly frightened by the political appeal of the Brannan Plan (high incomes to farmers and low food prices to the laboring man). Fourth, shifting support to livestock production by replacing crop price supports with direct payments generated opposition from southern Democrats for fear of jeopardizing existing programs for crops like tobacco, peanuts and cotton.

The EEC commission recognized at an early stage that policies which protected markets through high support prices and ever increasing taxpayer funds to finance stocks and surpluses created more problems than solutions. As early as 1968, EEC's Vice-President in charge of agriculture Sicco Mansholt proposed a complete reinstumentation of its agricultural policies to be later known as the Mansholt Plan (Marsh 1970; Uri 1970). In summary, farm structures were deemed outdated and market interventions ineffective so new measures were recommended that would facilitate structural adjustment in reducing the farm population, resulting in larger farms. Social-economic directives put forward included subsidies and credit for farm modernization, early retirement of farmers to make land available for farms to grow and subsidies to train and thus increase the efficiency of farmers. The plan failed because a structural policy whose objective is to have a half of all farms disappear did not generate sufficient political support among farm organizations. Price supports that prevent change are sure to fail but too rapid a change can cause social problems and political opposition. 


\section{Table 1: The Three Pillars of Agricultural Support under URRA}

\begin{tabular}{|c|c|}
\hline DEFINITION & REDUCTION COMMITMENT \\
\hline \multicolumn{2}{|l|}{ Market Access } \\
\hline $\begin{array}{l}\text { Includes measures such as } \\
\text { tariffs and quantitative re- } \\
\text { strictions which effectively } \\
\text { limit imports, thus enabling } \\
\text { producers to receive prices } \\
\text { higher than they would ob- } \\
\text { tain in the world market. }\end{array}$ & $\begin{array}{l}\text { Non-tariff barriers were converted to tariff equivalents as at a specified base period of } \\
\text { 1986- } 88 \text { (a process called tariffication). This along with existing tariffs were reduced } \\
\text { over the implementation period by an average of } 36 \text { percent. For items that were sub- } \\
\text { ject to tariffication, minimum access levels for imports were to rise from } 3 \text { to } 5 \text { percent } \\
\text { of base period, and current access levels were assured. These measures were imple- } \\
\text { mented through applying tariff quotas. Tariff and tariff quotas have been applied at } \\
\text { the individual product or tariff line level. }\end{array}$ \\
\hline \multicolumn{2}{|l|}{ Domestic Support } \\
\hline $\begin{array}{l}\text { Includes taxpayer-funded } \\
\text { outlays and take various } \\
\text { forms such as direct price } \\
\text { subsidies on output and in- } \\
\text { puts, income support, insur- } \\
\text { ance subsidies, etc. }\end{array}$ & $\begin{array}{l}\text { Levels of non-exempt support, the so-called Amber Box, were determined for each } \\
\text { country in what was termed the Aggregate Measurement of Support (AMS). The AMS } \\
\text { was subject to a } 20 \text { percent reduction from its } 1986-88 \text { base, over the implementation } \\
\text { period. AMS consists of two components: one is price support determined from the } \\
\text { difference between the administered support price and 1986-88 base price, multiplied } \\
\text { by quantity eligible for support. The other is non-exempt domestic subsidies. Exemp- } \\
\text { tions to reduction commitments are the green box, blue box, and de minimis support. }\end{array}$ \\
\hline \multicolumn{2}{|l|}{ Export Subsidies } \\
\hline $\begin{array}{l}\text { Includes payments on prod- } \\
\text { ucts being exported. }\end{array}$ & $\begin{array}{l}\text { The volume of subsidized exports was to be reduced by } 21 \text { percent and budget out- } \\
\text { lays on export subsidies by } 36 \text { percent on an individual commodity basis from their } \\
1986-90 \text { base period over the same implementation period as market access and do- } \\
\text { mestic support. }\end{array}$ \\
\hline
\end{tabular}

Source: World Trade Organization 


\section{Table 2: The Road to (and from) Doha-WTO Ministerials}

\section{SINGAPORE (DECEMBER 9-13, 1996)}

The first Ministerial since the creation of the WTO on January 1, 1995. Its objective was to assess the implementation of the commitments under the WTO agreements, review on-going negotiations, examine developments in world trade, and address the challenges in an evolving world economy. The Ministerial also launched the Integrated Framework for Trade Related Technical Assistance (IF), a multi-agency forum to assist the least developed countries (LDCs) to better integrate into the world economy and the multilateral trading system.

\section{GENEVA (MAY 18-20, 1998)}

Commemorated the $50^{\text {th }}$ anniversary of GATT. The Ministerial specifically rejected the use of any protectionist measures and noted that the WTO should work together with the World Bank and the IMF to improve the coherence of the international policy making. Concern was expressed over the marginalization of LDCs and low income small economies. The urgent need was also recognized to address the issue of chronic debt problem faced by many of the economies.

\section{SEATTLE (NOVEMBER 30 - DECEMBER 3, 1999)}

The Ministerial was supposed to launch what would have been the "Seattle Round" but ended in failure because of irreconcilable differences on how far agricultural trade reform should go. Three broad negotiating groups made visible presence in Seattle. The reformers (mainly United States and Cairns Group) wanted substantial cuts in tradedistorting policies. In contrast, the status quo countries, led by the European Union and Japan, generally favored a go-slow approach. Developing countries, making up the vast majority of WTO members, sought special treatment.

\section{DOHA (NOVEMBER 9-13, 2001)}

Launched the so-called "Doha Development Agenda" (the name changed from "Round" to underscore the involvement of developing countries in the global trade negotiations). A commitment was made to comprehensive negotiations aimed at substantial improvements in market access, reductions of, with a view to phasing out, all forms of export subsidies, and substantial reductions in trade-distorting domestic support. Special and differential treatment for developing countries was agreed upon as well as non-trade concerns to be taken into account.

\section{CANCÚN (SEPTEMBER 10-14, 2003)}

Three important developments took place prior this Ministerial. First, four West African countries presented the "Cotton Initiative" asking for the elimination of global cotton subsidies (see Box 5). Second, the European Union and the United States presented a joint framework paper for agricultural negotiation-it was viewed as a conservative approach to agricultural reform. Third, the G20-a group of developing countries led by Brazil, China, India and South Africa - presented their own, more ambitious, framework proposal. The Ministerial collapsed in view of the inability to reach consensus with Singapore Issues (investment, competition, and trade facilitation). However, differences concerning the future of the agricultural negotiations and the treatment of cotton contributed significantly to the collapse.

\section{GENEVA FOLLOW UP (AUGUST 2004)}

Under the "Framework Agreement" agreed in August 2004, trade-distorting domestic support will be subject to further cuts. During the first year, the sum of all trade-distorting support should not exceed 80 per cent of the sum of Total AMS plus permitted de minimis plus the agreed level of blue box payments. Furthermore, the Total AMS and permitted de minimis will be subject to substantial reductions and blue box subsidies will be capped at $5 \%$ of the total value of production during an historical period yet to be established. Finally, green box criteria will be reviewed and clarified with a view to ensuring at most minimal, trade-distorting effects.

\section{HONK KONG (DECEMBER 13-18, 2005)}

The main issues at this Ministerial are likely to be the criteria for selection of sensitive products, the definition and implementation of the tiered formula and the schedule of implementation of new disciplines in each of the three pillars of agricultural support. The methodology for product-specific caps on trade-distorting (amber box) domestic subsidies is expected to be discussed specifically as well as the base and reference periods for countries to make specific commitments for domestic support.

Source: World Trade Organization. 
Table 3: Composition of Agricultural Support in OECD

\begin{tabular}{lcrrrr}
\hline \hline & $1986-88$ & $1989-92$ & $1993-95$ & $1996-98$ & $1999-2001$ \\
\hline US\$ MILLION & & & & & \\
Value of Production & $\mathbf{5 7 5 , 5 7 8}$ & $\mathbf{7 0 2 , 8 0 9}$ & $\mathbf{7 5 2 , 5 5 4}$ & $\mathbf{7 5 1 , 2 2 1}$ & $\mathbf{6 7 2 , 3 8 9}$ \\
Total Support Estimate & $\mathbf{3 0 2 , 0 7 8}$ & $\mathbf{3 5 2 , 5 3 5}$ & $\mathbf{3 7 3 , 4 2 6}$ & $\mathbf{3 4 0 , 2 6 9}$ & $\mathbf{3 2 9 , 5 6 4}$ \\
Producer Support Estimate & $\mathbf{2 3 8 , 9 3 6}$ & $\mathbf{2 6 7 , 2 8 5}$ & $\mathbf{2 7 5 , 7 8 3}$ & $\mathbf{2 4 7 , 5 2 9}$ & $\mathbf{2 4 8 , 3 0 2}$ \\
Market Price Support & 184,539 & 207,724 & 201,779 & 164,896 & 160,142 \\
Budgetary Support & 54,097 & 58,733 & 73,561 & 82,932 & 88,202 \\
Output & 11,742 & 11,434 & 6,860 & 7,984 & 16,012 \\
Input Use & 20,328 & 22,981 & 24,289 & 23,618 & 20,671 \\
Area & 15,664 & 16,330 & 31,872 & 32,402 & 29,078 \\
Historical Entitlements & 515 & 610 & 2,791 & 9,163 & 13,179 \\
Input Constraints & 2,995 & 5,172 & 6,375 & 7,862 & 6,262 \\
Overall Farm Income & 2,853 & 2,207 & 1,373 & 1,902 & 3,000 \\
COMPONENTS OF SUPPORT AS A SHARE OF PSE (PERCENT) & & & \\
Market Price Support & 77.2 & 77.7 & 73.2 & 66.6 & 64.5 \\
Budgetary Support & 22.6 & 22.0 & 26.7 & 33.5 & 35.5 \\
Output & 4.9 & 4.3 & 2.5 & 3.2 & 6.4 \\
Input Use & 8.5 & 8.6 & 8.8 & 9.5 & 8.3 \\
Area & 6.6 & 6.1 & 11.6 & 13.1 & 11.7 \\
Historical Entitlements & 0.2 & 0.2 & 1.0 & 3.7 & 5.3 \\
Input Constraints & 1.3 & 1.9 & 2.3 & 3.2 & 2.5 \\
Overall Farm Income & 1.2 & 0.8 & 0.5 & 0.8 & 1.2 \\
\hline \hline Source OECD. & \multicolumn{3}{c}{} & &
\end{tabular}

Source: OECD. 
Table 4: Agricultural Support in OECD, 1999-2001 average (US\$ billion)

\begin{tabular}{|c|c|c|c|c|c|c|c|c|}
\hline & US & EU & Japan & Korea & Turkey & Mexico & Others & OECD \\
\hline \multicolumn{9}{|c|}{ TOTAL SUPPORT ESTIMATE } \\
\hline \multicolumn{9}{|c|}{ Where it comes from } \\
\hline Consumers & 20.6 & 58.8 & 64.5 & 19.0 & 5.5 & 4.8 & 9.3 & 182.5 \\
\hline Taxpayers & 76.8 & 54.3 & 17.8 & 4.7 & 4.5 & 3.0 & 10.0 & 171.1 \\
\hline Budget Revenue $^{1}$ & -2.0 & -0.5 & -17.5 & -2.2 & -0.3 & -0.8 & -0.8 & -24.1 \\
\hline \multicolumn{9}{|l|}{ Where it goes } \\
\hline Producers & 51.3 & 99.3 & 52.0 & 18.2 & 6.5 & 5.7 & 15.3 & 248.3 \\
\hline General Services & 22.8 & 9.5 & 12.7 & 3.2 & 3.2 & 0.7 & 2.9 & 55.1 \\
\hline Consumers & 21.4 & 3.8 & 0.1 & 0.1 & 0.0 & 0.6 & 0.3 & 26.2 \\
\hline TOTAL SUPPORT $^{2}$ & 95.5 & 112.6 & 64.8 & 21.5 & 9.6 & 7.0 & 18.5 & 329.6 \\
\hline \multicolumn{9}{|c|}{ ProducER SuPPORT ESTIMATE } \\
\hline \multicolumn{9}{|c|}{ Where it comes from ${ }^{3}$} \\
\hline Border measures & 18.7 & 60.9 & 47.0 & 17.2 & 5.1 & 3.6 & 7.7 & 160.1 \\
\hline Domestic measures & 32.6 & 38.5 & 5.0 & 0.9 & 1.4 & 2.1 & 7.6 & 88.2 \\
\hline \multicolumn{9}{|l|}{ Where it goes } \\
\hline Milk & 12.4 & 16.7 & 4.9 & 0.8 & 0.7 & 1.2 & 5.4 & 42.1 \\
\hline Beef & 1.4 & 20.6 & 1.7 & 1.2 & 0.7 & 0.2 & 1.6 & 27.1 \\
\hline Rice & 0.7 & 0.2 & 18.0 & 7.3 & nc & 0.3 & -0.2 & 26.4 \\
\hline Wheat & 4.9 & 9.5 & 0.8 & nc & 0.6 & 0.2 & 1.2 & 17.3 \\
\hline Corn & 8.3 & 2.7 & nc & nc & 0.1 & 1.6 & 0.1 & 12.9 \\
\hline Pig meat & 0.4 & 5.7 & 2.2 & 0.6 & nc & 0.1 & 1.0 & 10.1 \\
\hline Other commodities & 23.1 & 43.9 & 24.3 & 8.2 & 4.4 & 2.1 & 6.3 & 112.3 \\
\hline PRODUCER SUPPORT ${ }^{2}$ & 51.3 & 99.3 & 52.0 & 18.2 & 6.5 & 5.7 & 15.3 & 248.3 \\
\hline
\end{tabular}

${ }^{1}$ A minus (-) sign indicates the portion of the tax revenue that remains with the Treasury.

2 Equal to the sums under the headings "Where it comes from" and "Where it goes."

${ }^{3}$ Broadly speaking, border measures generate consumer-financed support while domestic measures corresponds to taxpayer-financed support. One exception is export subsidies that is a border measure but involves transfers from both consumers and taxpayers.

Source: OECD and authors calculations. 
Table 5: Characteristics of Agricultural Support in OECD, 1999-2001 average

\begin{tabular}{|c|c|c|c|c|c|c|c|}
\hline & \multicolumn{3}{|c|}{ TOTAL SUPPORT ESTIMATE } & \multirow[b]{2}{*}{$\begin{array}{c}\text { Per capita GDP } \\
(1995 \text { constant } \$)^{1}\end{array}$} & \multicolumn{3}{|c|}{ PRODUCER SUPPORT ESTIMATE } \\
\hline & $\begin{array}{c}\text { Total } \\
\text { (million \$) }\end{array}$ & $\begin{array}{c}\text { Share of GDP } \\
\text { (percent) }\end{array}$ & Per capita $(\$)$ & & $\begin{array}{c}\text { Total } \\
\text { (million \$) }\end{array}$ & $\begin{array}{l}\text { Per full-time } \\
\text { farmer }(\$)\end{array}$ & $\begin{array}{c}\text { Per hectare of } \\
\text { land (\$) }\end{array}$ \\
\hline European Union & 112,628 & 1.5 & 300 & 25,924 & 99,343 & 16,000 & 722 \\
\hline Japan & 64,775 & 1.5 & 511 & 44,343 & 51,980 & 25,000 & 10,682 \\
\hline Korea & 21,489 & 5.0 & 456 & 12,618 & 18,170 & 23,000 & 9,293 \\
\hline Turkey & 9,649 & 5.1 & 145 & 3,061 & 6,522 & nc & 162 \\
\hline Canada & 5,231 & 0.8 & 171 & 22,147 & 3,930 & 9,000 & 53 \\
\hline Switzerland & 5,047 & 2.0 & 704 & 46,183 & 4,480 & 29,000 & 2,835 \\
\hline Norway & 2,489 & 1.5 & 556 & 37,661 & 2,274 & 35,000 & 2,187 \\
\hline Poland & 1,934 & 1.2 & 50 & 4,142 & 1,676 & 1,000 & 90 \\
\hline Australia & 1,376 & 0.4 & 72 & 23,743 & 947 & 2,000 & 2 \\
\hline Iceland & 156 & 1.9 & 557 & 30,747 & 136 & 29,000 & 71 \\
\hline OECD & 329,564 & 1.3 & 295 & & 248,302 & 11,000 & 192 \\
\hline
\end{tabular}

${ }^{1}$ Refers to $1999-2000$ average

Source: OECD (2002) and World Bank (World Development Indicators) 
Table 6: Decomposing Producer Support in OECD Countries

\begin{tabular}{|c|c|c|c|c|c|}
\hline & $\begin{array}{l}\text { Producer Sup- } \\
\text { port Estimate } \\
\text { (US \$ million) }\end{array}$ & $\begin{array}{c}\text { Market Price } \\
\text { Support } \\
\text { (US \$ million) }\end{array}$ & $\begin{array}{c}\text { Budgetary } \\
\text { Support } \\
\text { (US \$ million) }\end{array}$ & $\begin{array}{c}\text { Market Price } \\
\text { Support } \\
\text { (\% of PSE) }\end{array}$ & $\begin{array}{c}\text { Budgetary } \\
\text { Support } \\
\text { (\% of PSE) }\end{array}$ \\
\hline \multicolumn{6}{|l|}{ 1986-88 } \\
\hline European Union & 93,719 & 80,257 & 13,462 & 86 & 14 \\
\hline Japan & 49,498 & 44,354 & 5,144 & 90 & 10 \\
\hline United States & 41,839 & 19,533 & 22,306 & 47 & 53 \\
\hline Korea & 12,120 & 11,997 & 123 & 99 & 1 \\
\hline Canada & 5,667 & 2,769 & 2,898 & 49 & 51 \\
\hline Switzerland & 5,063 & 4,133 & 930 & 82 & 18 \\
\hline Turkey & 2,779 & 1,884 & 895 & 68 & 32 \\
\hline Norway & 2,628 & 1,188 & 1,440 & 45 & 55 \\
\hline Czech Republic ${ }^{1}$ & 1,670 & 1,590 & 80 & 95 & 5 \\
\hline Australia & 1,285 & 599 & 686 & 47 & 53 \\
\hline Hungary $^{1}$ & 891 & 661 & 230 & 74 & 26 \\
\hline Slovakia ${ }^{1}$ & 675 & 375 & 300 & 56 & 44 \\
\hline Poland 1 & 528 & 2 & 526 & 0 & 100 \\
\hline New Zealand & 476 & 92 & 384 & 19 & 81 \\
\hline Iceland & 193 & 169 & 24 & 88 & 12 \\
\hline Mexico & -266 & $-1,710$ & - & - & - \\
\hline OECD & 238,936 & 184,539 & 54,397 & 77 & 23 \\
\hline \multicolumn{6}{|l|}{ 1999-2001 } \\
\hline European Union & 99,343 & 60,863 & 38,480 & 61 & 39 \\
\hline Japan & 51,979 & 46,974 & 5,005 & 90 & 10 \\
\hline United States & 51,256 & 18,662 & 32,594 & 36 & 64 \\
\hline Korea & 18,170 & 17,234 & 936 & 95 & 5 \\
\hline Turkey & 6,522 & 5,093 & 1,429 & 78 & 22 \\
\hline Mexico & 5,694 & 3,625 & 2,069 & 4 & 36 \\
\hline Switzerland & 4,480 & 2,589 & 1,891 & 58 & 42 \\
\hline Canada & 3,930 & 1,998 & 1,932 & 51 & 49 \\
\hline Norway & 2,274 & 891 & 1,383 & 39 & 61 \\
\hline Poland & 1,676 & 1,162 & 514 & 69 & 31 \\
\hline Australia & 947 & 97 & 850 & 10 & 90 \\
\hline Hungary & 881 & 427 & 454 & 48 & 52 \\
\hline Czech Republic & 655 & 366 & 289 & 56 & 44 \\
\hline Slovakia & 292 & 48 & 244 & 16 & 84 \\
\hline Iceland & 136 & 66 & 70 & 49 & 51 \\
\hline New Zealand & 67 & 47 & 20 & 70 & 30 \\
\hline OECD & 248,302 & 160,142 & 88,160 & 64 & 36 \\
\hline
\end{tabular}

1 1991-93 average

Source: OECD and authors calculations. 


\section{Table 7: PSE - Smaller and Large Impact on Production and Trade}

\begin{tabular}{|c|c|c|c|c|c|}
\hline & $\begin{array}{c}\text { Producer } \\
\text { Support } \\
\text { Estimate } \\
\text { (US \$ million) }\end{array}$ & $\begin{array}{l}\text { Large impact } \\
\text { on production } \\
\text { and trade } \\
\text { (US \$ million) }\end{array}$ & $\begin{array}{l}\text { Smaller impact } \\
\text { on production } \\
\text { and trade } \\
\text { (US } \$ \text { million) }\end{array}$ & $\begin{array}{l}\text { Large impact } \\
\text { on produc- } \\
\text { tion and trade } \\
(\% \text { of PSE })\end{array}$ & $\begin{array}{c}\text { Smaller impact } \\
\text { on production } \\
\text { and trade } \\
(\% \text { of PSE })\end{array}$ \\
\hline \multicolumn{6}{|l|}{$1986-88$} \\
\hline European Union & 93,719 & 90,291 & 3,428 & 96 & 4 \\
\hline Japan & 49,498 & 47,939 & 1,560 & 97 & 3 \\
\hline United States & 41,839 & 28,978 & 12,861 & 69 & 31 \\
\hline Korea & 12,120 & 12,085 & 35 & 100 & 0 \\
\hline Canada & 5,667 & 4,601 & 1,065 & 81 & 19 \\
\hline Switzerland & 5,063 & 4,609 & 454 & 91 & 9 \\
\hline Turkey & 2,779 & 2,779 & 0 & 100 & 0 \\
\hline Norway & 2,628 & 2,341 & 287 & 89 & 11 \\
\hline Czech Republic ${ }^{3}$ & 1,670 & 1,667 & 3 & 100 & 0 \\
\hline Australia & 1,285 & 1,012 & 273 & 79 & 21 \\
\hline Hungary ${ }^{3}$ & 891 & 822 & 69 & 92 & 8 \\
\hline Slovakia $^{3}$ & 675 & 451 & 224 & 67 & 33 \\
\hline Poland ${ }^{3}$ & 528 & 519 & 9 & 98 & 2 \\
\hline New Zealand & 476 & 286 & 190 & 60 & 40 \\
\hline Iceland & 193 & 192 & 1 & 99 & 1 \\
\hline Mexico & -266 & na & na & - & - \\
\hline Total OECD & 238,936 & 216,609 & 22,327 & 91 & 9 \\
\hline \multicolumn{6}{|l|}{ 1999-2001 } \\
\hline European Union & 99,343 & 71,048 & 28,295 & 72 & 29 \\
\hline Japan & 51,979 & 50,956 & 1,023 & 98 & 2 \\
\hline United States & 51,256 & 34,824 & 16,432 & 68 & 32 \\
\hline Korea & 18,170 & 17,730 & 440 & 98 & 2 \\
\hline Turkey & 6,522 & 6,386 & 136 & 98 & 2 \\
\hline Mexico & 5,694 & 4,456 & 1,238 & 78 & 22 \\
\hline Switzerland & 4,480 & 2,986 & 1,494 & 67 & 33 \\
\hline Canada & 3,930 & 2,643 & 1,287 & 67 & 33 \\
\hline Norway & 2,274 & 1,776 & 498 & 78 & 22 \\
\hline Poland & 1,676 & 1,654 & 22 & 99 & 1 \\
\hline Australia & 947 & 737 & 210 & 78 & 22 \\
\hline Hungary & 881 & 801 & 80 & 91 & 9 \\
\hline Czech Republic & 655 & 480 & 175 & 73 & 27 \\
\hline Slovakia & 292 & 166 & 126 & 57 & 43 \\
\hline Iceland & 136 & 116 & 20 & 85 & 15 \\
\hline New Zealand & 67 & 66 & 1 & 99 & 1 \\
\hline Total OECD & 248,302 & 196,824 & 51,478 & 79 & 21 \\
\hline
\end{tabular}

${ }^{1}$ It includes market price support, payments based on output, and payments based on input use.

2 It includes payments based on area planted/animal numbers, historical entitlements, input constraints, and overall farm income.

3 1991-93 average

Source: OECD and authors calculations. 


\section{Table 8: Transfer Efficiency of Agricultural Support}

\begin{tabular}{lcccc}
\hline \hline & $\begin{array}{c}\text { Deficiency } \\
\text { payments }\end{array}$ & $\begin{array}{c}\text { Market price } \\
\text { support }\end{array}$ & $\begin{array}{c}\text { Area } \\
\text { payments }\end{array}$ & $\begin{array}{c}\text { Input } \\
\text { subsidies }\end{array}$ \\
\hline Farm household labor & 0.14 & 0.10 & 0.01 & 0.08 \\
Farm household land & 0.12 & 0.13 & 0.46 & 0.09 \\
Landlords & 0.14 & 0.13 & 0.45 & 0.09 \\
Input suppliers & 0.39 & 0.36 & 0.03 & 0.67 \\
Resource costs & 0.21 & 0.28 & 0.05 & 0.07 \\
Total & $\$ 1.00$ & $\$ 1.00$ & $\$ 1.00$ & $\$ 1.00$ \\
Farm households & $26 \%$ & $23 \%$ & $47 \%$ & $17 \%$ \\
Others & $74 \%$ & $77 \%$ & $53 \%$ & $83 \%$ \\
\hline \hline
\end{tabular}

Notes: The numbers indicate how much out of every $\$ 1$ of each type of support goes to each of the five types of inputs. The sum of the first two rows (denoted as Farm households in the penultimate row) represents the share that goes to the household income.

Source: OECD (2001). 


\section{Table 9: The Nature of the AMS, 1999 (US\$ million)}

\begin{tabular}{lrrrrr}
\hline \hline & EU & US & Japan & Korea & Canada \\
\hline SUPPORT EXEMPT FROM AMS & & & & & \\
$\quad$ Green Box & 21,216 & 30,591 & 23,664 & 4,591 & 1,177 \\
Blue Box & 21,114 & - & 817 & - & - \\
$\quad$ de minimis & \\
TOTAL & 493 & 7,435 & 288 & 4,110 & 742 \\
SUPPORT INCLUDED IN AMS & $\mathbf{4 2 , 8 2 3}$ & $\mathbf{3 8 , 0 2 6}$ & $\mathbf{2 4 , 7 6 9}$ & $\mathbf{8 , 7 0 1}$ & $\mathbf{1 , 9 1 9}$ \\
$\quad$ & & & & \\
$\quad$ Taxpayer Financed & 2,270 & 10,942 & 1,313 & - & 336 \\
$\quad$ Consumer Financed & 48,814 & 5,921 & 5,459 & 1,306 & 296 \\
NOTIFICATION TO THE WTO & $\mathbf{5 1 , 0 8 4}$ & $\mathbf{1 6 , 8 6 2}$ & $\mathbf{6 , 5 8 8}$ & $\mathbf{1 , 3 0 6}$ & $\mathbf{6 3 2}$ \\
WTO Ceiling & 73,518 & 20,000 & 36,333 & $\mathbf{1 , 5 7 7}$ & 3,016 \\
\hline \hline
\end{tabular}

${ }^{1}$ It includes both product and non-product specific support.

2 The Green Box for the US includes $\$ 5,471$ million in product specific support but excludes $\$ 33,050$ million for domestic food aid.

Source: Country notifications to the WTO. 
Table 10: Comparing PSE and AMS, 1997-99

\begin{tabular}{|c|c|c|c|c|c|}
\hline & \multicolumn{3}{|c|}{ SUPPORT (US \$ BILLION) } & \multicolumn{2}{|c|}{ CHANGE IN SUPPORT } \\
\hline & 1997 & 1998 & 1999 & $1997-98$ & 1998-99 \\
\hline \multicolumn{6}{|c|}{ European Union } \\
\hline AMS & 56.7 & 52.6 & 51.1 & -4.1 & -1.4 \\
\hline PSE & 105.0 & 114.4 & 115.3 & 9.4 & 0.9 \\
\hline \multicolumn{6}{|c|}{ United States } \\
\hline AMS & 6.0 & 10.0 & 16.8 & 4.0 & 7.0 \\
\hline PSE & 30.7 & 48.6 & 55.4 & 17.8 & 6.9 \\
\hline \multicolumn{6}{|l|}{ Japan } \\
\hline AMS & 26.2 & 5.9 & 6.6 & -20.3 & 0.7 \\
\hline PSE & 48.4 & 47.6 & 53.8 & -0.8 & 6.2 \\
\hline \multicolumn{6}{|l|}{ Korea } \\
\hline AMS & 2.0 & 1.1 & 1.3 & -0.9 & 0.2 \\
\hline PSE & 20.2 & 12.6 & 18.3 & -7.6 & 5.7 \\
\hline \multicolumn{6}{|l|}{ Turkey } \\
\hline AMS & 0.0 & 0.0 & 0.0 & 0.0 & 0.0 \\
\hline PSE & 7.3 & 10.5 & 7.7 & 2.6 & -2.8 \\
\hline \multicolumn{6}{|l|}{ Mexico } \\
\hline AMS & 0.4 & 0.4 & na & 0.0 & na \\
\hline PSE & 4.0 & 4.1 & 4.5 & 0.1 & 0.4 \\
\hline \multicolumn{6}{|l|}{ Canada } \\
\hline AMS & 0.7 & 0.5 & 0.4 & -0.1 & -0.2 \\
\hline PSE & 3.2 & 3.5 & 3.7 & 0.3 & 0.2 \\
\hline
\end{tabular}

Note: Absolute differences may not match exactly the annual difference of support measures due to rounding.

Source: OECD and country notifications to the WTO. 


\section{Table 11: The Distributional Impact of a Hypothetical Decoupled Support}

\section{Program}

\begin{tabular}{|c|c|c|c|c|c|c|c|}
\hline \multirow[b]{2}{*}{$\begin{array}{c}\text { Area } \\
\text { (hectares) }\end{array}$} & \multirow[b]{2}{*}{$\begin{array}{c}\text { Output } \\
\text { (tons) }\end{array}$} & \multirow[b]{2}{*}{$\begin{array}{c}\text { Value of } \\
\text { output }\end{array}$} & \multicolumn{2}{|c|}{ Value of support under } & \multicolumn{2}{|c|}{ Total income with } & \multirow{2}{*}{$\begin{array}{c}\text { Total } \\
\text { Gains }(+) / \\
\text { Losses(-) }\end{array}$} \\
\hline & & & $\begin{array}{c}\text { Price } \\
\text { support }\end{array}$ & $\begin{array}{c}\text { Decoupled } \\
\text { payment }\end{array}$ & $\begin{array}{c}\text { Price } \\
\text { support }\end{array}$ & $\begin{array}{c}\text { Decoupled } \\
\text { payments }\end{array}$ & \\
\hline \multicolumn{8}{|c|}{$\$ 100$ decoupled support and 1.5 tons yield (per hectare) } \\
\hline 1 & 1.5 & 0 & 0 & 100 & 0 & 100 & 100 \\
\hline 10 & 15 & 3,000 & 750 & 1,000 & 3,750 & 4,000 & 250 \\
\hline 50 & 75 & 15,000 & 3,750 & 5,000 & 18,750 & 20,000 & 1,250 \\
\hline 100 & 150 & 30,000 & 7,500 & 10,000 & 37,500 & 40,000 & 2,500 \\
\hline 200 & 300 & 60,000 & 15,000 & 10,000 & 75,000 & 70,000 & $-5,000$ \\
\hline 500 & 750 & 150,000 & 37,500 & 10,000 & 187,500 & 160,000 & $-27,500$ \\
\hline \multicolumn{8}{|c|}{$\$ 100$ decoupled support and 1.0 tons yield (per hectare) } \\
\hline 1 & 1 & 0 & 0 & 100 & 0 & 100 & 100 \\
\hline 10 & 10 & 2,000 & 500 & 1,000 & 2,500 & 3,000 & 500 \\
\hline 50 & 50 & 10,000 & 2,500 & 5,000 & 12,500 & 15,000 & 2,500 \\
\hline 100 & 100 & 20,000 & 5,000 & 10,000 & 25,000 & 30,000 & 5,000 \\
\hline 200 & 200 & 40,000 & 10,000 & 10,000 & 50,000 & 50,000 & 0 \\
\hline 500 & 500 & 100,000 & 25,000 & 10,000 & 125,000 & 110,000 & $-15,000$ \\
\hline \multicolumn{8}{|c|}{ \$150 decoupled support and 1.5 tons yield (per hectare) } \\
\hline 1 & 1.5 & 0 & 0 & 150 & 0 & 150 & 150 \\
\hline 10 & 15 & 3,000 & 750 & 1,500 & 3,750 & 4,500 & 750 \\
\hline 50 & 75 & 15,000 & 3,750 & 7,500 & 18,750 & 22,500 & 3,750 \\
\hline 100 & 150 & 30,000 & 7,500 & 15,000 & 37,500 & 45,000 & 7,500 \\
\hline 200 & 300 & 60,000 & 15,000 & 15,000 & 75,000 & 75,000 & 0 \\
\hline 500 & 750 & 150,000 & 37,500 & 15,000 & 187,500 & 165,000 & $-22,500$ \\
\hline \multicolumn{8}{|c|}{ \$150 decoupled support and 1.0 tons yield (per hectare) } \\
\hline 1 & 1 & 0 & 0 & 150 & 0 & 150 & 150 \\
\hline 10 & 10 & 2,000 & 500 & 1,500 & 2,500 & 3,500 & 1,000 \\
\hline 50 & 50 & 10,000 & 2,500 & 7,500 & 12,500 & 17,500 & 5,000 \\
\hline 100 & 100 & 20,000 & 5,000 & 15,000 & 25,000 & 35,000 & 10,000 \\
\hline 200 & 200 & 40,000 & 10,000 & 15,000 & 50,000 & 55,000 & 5,000 \\
\hline 500 & 500 & 100,000 & 25,000 & 15,000 & 125,000 & 115,000 & $-10,000$ \\
\hline
\end{tabular}

Notes: The market price is assumed at $\$ 200 /$ ton. Producers below one hectare are assumed to use their entire output for home consumption thus receiving no support. Price support is assumed at $\$ 50$ per ton. There is an upper limit of 100 hectares for decoupled support. The difference between 'Total income' under decoupled payment and 'Total income' under price support.

Source: Authors calculations. 


\section{Table 12: Chronology of Significant Decoupling and Recoupling Episodes}

\begin{tabular}{|c|c|c|}
\hline Year & Country & Policy Change \\
\hline 1985 & United States & 1985 Farm Bill “freezes” government payment yields per acre. \\
\hline 1992 & European Union & $\begin{array}{l}\text { MacSharry reforms of the Common Agricultural Policy reduce price supports } \\
\text { and introduce direct payments linked to area planted or number of animals, } \\
\text { both subject to overall ceilings (with yields per hectare frozen). }\end{array}$ \\
\hline 1994 & Mexico & $\begin{array}{l}\text { PROCAMPO introduces payments based on both historical acres and yields } \\
\text { up to } 2008 \text { with a phase-out of import barriers under NAFTA, input subsi- } \\
\text { dies, and activities of the state trading monopoly. }\end{array}$ \\
\hline 1996 & United States & $\begin{array}{l}1996 \text { Farm Bill eliminates target prices, introduces decoupled historical enti- } \\
\text { tlements, the so-called production flexibility contract payments, set to expire } \\
\text { in } 2002 \text {. }\end{array}$ \\
\hline 1996 & Mexico & $\begin{array}{l}\text { Base acres can be switched to other crops or enterprises, and rural develop- } \\
\text { ment policy is launched to foster productivity. }\end{array}$ \\
\hline 1998 & United States & $\begin{array}{l}\text { Emergency market loss assistance payments proportionally linked to PFCs, } \\
\text { effectively reversed the } 1996 \text { Farm Bill by linking emergency support to cur- } \\
\text { rent market developments. }\end{array}$ \\
\hline 2000 & European Union & Agenda 2000 extends, deepens, and widens the MacSharry reforms. \\
\hline 2001 & Turkey & $\begin{array}{l}\text { Direct income support program reduces some administered prices and input } \\
\text { subsidies. Only minor changes in border policies. }\end{array}$ \\
\hline 2002 & United States & $\begin{array}{l}2002 \text { Farm Bill reintroduces target prices in order to replace emergency pay- } \\
\text { ments with countercyclical payments, updates PFCs basis and replaces them } \\
\text { with direct payments, adds new crops, and allows base acres and payment } \\
\text { yields to be updated. }\end{array}$ \\
\hline 2002 & Mexico & $\begin{array}{l}\text { Reintroduces target prices and input subsidies. PROCAMPO remains largely } \\
\text { unchanged. }\end{array}$ \\
\hline 2003 & European Union & $\begin{array}{l}\text { Mid-term review, resulting in June } 2003 \text { agreement to switch most direct } \\
\text { payments to decoupled payments based on historical reference, with entitle- } \\
\text { ments sold with or without land; some support prices to decline in 2005-07. }\end{array}$ \\
\hline 2004 & European Union & $\begin{array}{l}\text { Decoupled payments are also extended to cotton, olive oil, and tobacco sec- } \\
\text { tors. }\end{array}$ \\
\hline
\end{tabular}

Source: Compiled by the authors. 
Table 13: Characteristics of Four Decoupled Support Programs

\begin{tabular}{|c|c|c|c|c|}
\hline & $\begin{array}{l}\text { EU: CAP Reform } \\
\text { Implemented } 1993\end{array}$ & $\begin{array}{l}\text { Mexico: PROCAMPO } \\
\text { Implemented } 1994\end{array}$ & $\begin{array}{c}\text { US: FAIR Act } \\
\text { Implemented } 1996\end{array}$ & $\begin{array}{c}\text { Turkey: DIS } \\
\text { Implemented } 2001\end{array}$ \\
\hline Objective & $\begin{array}{l}\text { To compensate producers } \\
\text { from a reduction in support } \\
\text { prices }\end{array}$ & $\begin{array}{l}\text { To compensate producers for } \\
\text { elimination of guarantee } \\
\text { prices on support crops }\end{array}$ & $\begin{array}{l}\text { To compensate producers for } \\
\text { the elimination of deficiency } \\
\text { payments }\end{array}$ & $\begin{array}{l}\text { To cover the reduction in in- } \\
\text { come associated with the re- } \\
\text { moval of administered prices }\end{array}$ \\
\hline Payment basis & $\begin{array}{l}\text { Average acreage in support } \\
\text { crops during 1989-1991 }\end{array}$ & $\begin{array}{l}\text { Average acreage in support } \\
\text { crops during 1991-93 }\end{array}$ & $\begin{array}{l}\text { Acreage for which deficiency } \\
\text { payments were received dur- } \\
\text { ing 1990-95 }\end{array}$ & $\begin{array}{l}\text { Wheat, tobacco, hazelnut, } \\
\text { sugarbeet, maize, cotton, ol- } \\
\text { ives, and tea }\end{array}$ \\
\hline $\begin{array}{l}\text { Supported } \\
\text { products }\end{array}$ & $\begin{array}{l}\text { Wheat, maize, barley, rye, } \\
\text { oats, rapeseed sunflower, } \\
\text { soybeans, dried pulses, } \\
\text { beans, tobacco, beef, lamb }\end{array}$ & $\begin{array}{l}\text { Wheat, maize, sorghum, bar- } \\
\text { ley, rice, cotton, beans, soy- } \\
\text { beans, safflower }\end{array}$ & $\begin{array}{l}\text { Wheat, maize sorghum, bar- } \\
\text { ley, rice, cotton, oats }\end{array}$ & All marketable crops \\
\hline Time profile & $\begin{array}{l}\text { Fixed in nominal terms; no } \\
\text { expiration date but subject to } \\
\text { future CAP reforms }\end{array}$ & $\begin{array}{l}\text { Total of } 15 \text { years; first } 10 \\
\text { years fixed in real terms; de- } \\
\text { clining in the last } 5 \text { years }\end{array}$ & $\begin{array}{l}\text { Program lapses after } 7 \text { years } \\
\text { unless extended }\end{array}$ & No expiration date \\
\hline Payment limits & None & $\$ 6,700$ per farm & $\$ 40,000$ per farm & $\$ 5,000$ per farm \\
\hline $\begin{array}{l}\text { Restrictions on } \\
\text { the use of land }\end{array}$ & $\begin{array}{l}\text { Should be allocated to sup- } \\
\text { port crops; large producers } \\
\text { must put into fallow a prede- } \\
\text { termined level of support- } \\
\text { crop land. }\end{array}$ & $\begin{array}{l}\text { Should be allocated to sup- } \\
\text { port crops but since } 1996 \text { land } \\
\text { could be allocated to other } \\
\text { agricultural uses }\end{array}$ & $\begin{array}{l}\text { Should be kept in agriculture } \\
\text { (excluding fruits and vegeta- } \\
\text { bles); must be in compliance } \\
\text { with existing conservation } \\
\text { plans }\end{array}$ & No restriction on land use. \\
\hline
\end{tabular}

Notes: The characteristics of these programs were valid as of the beginning of implementation.

Source: Baffes and Meerman (1988); World Bank (2001). 


\section{Table 14: Composition of Agricultural Support in the United States}

\begin{tabular}{lrrrrr}
\hline \hline & $1986-88$ & $1989-92$ & $1993-95$ & $1996-98$ & $1999-2001$ \\
\hline US \$ MILLION & & & & & \\
Value of Production & $\mathbf{1 4 3 , 5 3 7}$ & $\mathbf{1 6 8 , 6 1 5}$ & $\mathbf{1 8 4 , 2 3 9}$ & $\mathbf{1 9 9 , 9 9 0}$ & $\mathbf{1 9 2 , 4 1 7}$ \\
Total Support Estimate & $\mathbf{6 8 , 5 4 0}$ & $\mathbf{7 2 , 7 7 9}$ & $\mathbf{7 9 , 0 6 0}$ & $\mathbf{8 1 , 7 1 5}$ & $\mathbf{9 5 , 4 5 5}$ \\
Producer Support Estimate & $\mathbf{4 1 , 8 3 9}$ & $\mathbf{3 4 , 3 2 6}$ & $\mathbf{3 1 , 0 9 1}$ & $\mathbf{3 6 , 3 8 4}$ & $\mathbf{5 1 , 2 5 6}$ \\
Market Price Support & 19,533 & 17,825 & 16,969 & $\mathbf{1 7 , 8 6 4}$ & 18,662 \\
Budgetary Support & 22,306 & 16,501 & 14,123 & 18,519 & 32,594 \\
Output & 2,919 & 510 & 241 & 1,644 & 9,285 \\
Input Use & 6,526 & 6,574 & 6,003 & 6,088 & 6,877 \\
Area & 11,313 & 6,897 & 5,396 & 1,247 & 2,722 \\
Historical Entitlements & 0 & 0 & 0 & 6,647 & 10,085 \\
Input Constraints & 637 & 1,776 & 1,963 & 1,940 & 1,844 \\
Overall Farm Income & 912 & 743 & 520 & 954 & 1,780 \\
COMPONENTS OF SUPPORT AS A SHARE OF PSE (PERCENT) & & & \\
Market Price Support & 46.7 & 51.9 & 54.6 & 49.1 & 36.4 \\
Budgetary Support & 53.3 & 48.1 & 45.4 & 50.9 & 63.6 \\
Output & 7.0 & 1.5 & 0.8 & 4.5 & 18.1 \\
Input Use & 15.6 & 19.2 & 19.3 & 16.7 & 13.4 \\
Area & 27.0 & 20.1 & 17.4 & 3.4 & 5.3 \\
Historical Entitlements & 0.0 & 0.0 & 0.0 & 18.3 & 19.7 \\
Input Constraints & 1.5 & 5.2 & 6.3 & 5.3 & 3.6 \\
Overall Farm Income & 2.2 & 2.2 & 1.7 & 2.6 & 3.5 \\
\hline \hline Source: OECD & & & & \\
\hline
\end{tabular}

Source: OECD 
Table 15: Composition of Agricultural Support in the European Union

\begin{tabular}{lrrrrr}
\hline \hline & $1986-88$ & $1989-92$ & $1993-95$ & $1996-98$ & $1999-2001$ \\
\hline US \$ MILLION & & & & & \\
Value of Production & $\mathbf{2 1 4 , 8 4 9}$ & $\mathbf{2 7 5 , 7 7 0}$ & $\mathbf{2 8 6 , 6 5 8}$ & $\mathbf{2 9 1 , 4 2 7}$ & $\mathbf{2 3 7 , 9 9 0}$ \\
Total Support Estimate & $\mathbf{1 0 9 , 6 5 4}$ & $\mathbf{1 3 8 , 9 2 7}$ & $\mathbf{1 3 3 , 0 5 0}$ & $\mathbf{1 2 9 , 3 2 8}$ & $\mathbf{1 1 2 , 6 2 8}$ \\
Producer Support Estimate & $\mathbf{9 3 , 7 1 9}$ & $\mathbf{1 1 7 , 0 9 7}$ & $\mathbf{1 1 6 , 5 1 9}$ & $\mathbf{1 1 1 , 9 6 6}$ & $\mathbf{9 9 , 3 4 3}$ \\
Market Price Support & 80,257 & 93,282 & 76,084 & 64,989 & 60,863 \\
Budgetary Support & 13,446 & 23,327 & 40,279 & 47,468 & 38,693 \\
Output & 5,009 & 6,769 & 2,999 & 3,945 & 3,644 \\
Input Use & 5,025 & 7,135 & 8,133 & 8,446 & 6,540 \\
Area & 2,701 & 6,987 & 24,326 & 29,419 & 24,733 \\
Historical Entitlements & 0 & 559 & 1,466 & 1,007 & 597 \\
Input Constraints & 711 & 1,877 & 3,356 & 4,650 & 3,178 \\
Overall Farm Income & 0 & 0 & 0 & 2 & 0 \\
COMPONENTS OF SUPPORT AS A SHARE OF PSE (PERCENT) & & & \\
Market Price Support & 85.6 & 79.7 & 65.3 & 58.0 & 61.3 \\
Budgetary Support & 14.3 & 19.9 & 34.6 & 42.4 & 38.9 \\
Output & 5.3 & 5.8 & 2.6 & 3.5 & 3.7 \\
Input Use & 5.4 & 6.1 & 7.0 & 7.5 & 6.6 \\
Area & 2.9 & 6.0 & 20.9 & 26.3 & 24.9 \\
Historical Entitlements & 0.0 & 0.5 & 1.3 & 0.9 & 0.6 \\
Input Constraints & 0.8 & 1.6 & 2.9 & 4.2 & 3.2 \\
Overall Farm Income & 0.0 & 0.0 & 0.0 & 0.0 & 0.0 \\
\hline \hline Source: OECD & & & &
\end{tabular}

Source: OECD 


\section{Table 16: Composition of Agricultural Support in Mexico}

\begin{tabular}{|c|c|c|c|c|c|}
\hline & $1986-88$ & 1989-92 & 1993-95 & $1996-98$ & 1999-2001 \\
\hline \multicolumn{6}{|l|}{ US \$ MILLION } \\
\hline Value of Production & 15,412 & 25,209 & 26,186 & 27,033 & 30,328 \\
\hline Total Support Estimate & 1,287 & 8,121 & 7,558 & 4,858 & 6,999 \\
\hline Producer Support Estimate & -266 & 5,718 & 5,060 & 3,190 & 5,694 \\
\hline Market Price Support & $-1,710$ & 4,025 & 2,918 & 1,495 & 3,625 \\
\hline Budgetary Support & 1,444 & 1,692 & 2,142 & 1,695 & 2,068 \\
\hline Output & 1 & 26 & 52 & 4 & 110 \\
\hline Input Use & 1,442 & 1,663 & 1,308 & 676 & 721 \\
\hline Area & 0 & 3 & 6 & 62 & 61 \\
\hline Historical Entitlements & 0 & 0 & 776 & 925 & 1,112 \\
\hline Input Constraints & 0 & 0 & 0 & 0 & 0 \\
\hline Overall Farm Income & 0 & 0 & 0 & 27 & 63 \\
\hline \multicolumn{6}{|c|}{ COMPONENTS OF SUPPORT AS A SHARE OF PSE (PERCENT) } \\
\hline Market Price Support & - & 70.4 & 57.7 & 46.9 & 63.7 \\
\hline Budgetary Support & - & 29.6 & 42.3 & 53.1 & 36.3 \\
\hline Output & - & 0.5 & 1.0 & 0.1 & 1.9 \\
\hline Input Use & - & 29.1 & 25.8 & 21.2 & 12.7 \\
\hline Area & - & 0.1 & 0.1 & 1.9 & 1.1 \\
\hline Historical Entitlements & - & 0.0 & 15.3 & 29.0 & 19.5 \\
\hline Input Constraints & - & 0.0 & 0.0 & 0.0 & 0.0 \\
\hline Overall Farm Income & - & 0.0 & 0.0 & 0.8 & 1.1 \\
\hline
\end{tabular}

Note: The minus (-) sign of the producer support estimate for 1986-88 indicates taxation. The corresponding shares are not reported.

Source: OECD 
Table 17: Composition of Agricultural Support in Turkey

\begin{tabular}{lrrrrr}
\hline \hline & $1986-88$ & $1989-92$ & $1993-95$ & $1996-98$ & $1999-2001$ \\
\hline US \$ MILLION & & & & & \\
Value of Production & $\mathbf{1 8 , 3 4 3}$ & $\mathbf{2 6 , 8 5 9}$ & $\mathbf{2 9 , 1 5 8}$ & $\mathbf{3 4 , 0 6 8}$ & $\mathbf{2 9 , 4 5 8}$ \\
Total Support Estimate & $\mathbf{3 , 0 9 2}$ & $\mathbf{7 , 2 1 2}$ & $\mathbf{6 , 0 2 7}$ & $\mathbf{1 0 , 7 0 5}$ & $\mathbf{9 , 6 4 9}$ \\
Producer Support Estimate & $\mathbf{2 , 7 7 9}$ & $\mathbf{6 , 1 2 7}$ & $\mathbf{4 , 6 7 5}$ & $\mathbf{7 , 7 9 1}$ & $\mathbf{6 , 5 2 2}$ \\
Market Price Support & 1,884 & 4,784 & 2,712 & 5,710 & 5,093 \\
Budgetary Support & 895 & 1,344 & 1,962 & 2,081 & 1,429 \\
Output & 11 & 30 & 242 & 104 & 337 \\
Input Use & 885 & 1,314 & 1,720 & 1,978 & 957 \\
Area & 0 & 0 & 0 & 0 & 0 \\
Historical Entitlements & 0 & 0 & 0 & 0 & 136 \\
Input Constraints & 0 & 0 & 0 & 0 & 0 \\
Overall Farm Income & 0 & 0 & 0 & 0 & 0 \\
COMPONENTS OF SUPPORT AS A SHARE OF PSE (PERCENT) & & & 78.1 \\
Market Price Support & 67.8 & 78.1 & 58.0 & 73.3 & 21.9 \\
Budgetary Support & 32.2 & 21.9 & 42.0 & 26.7 & 5.2 \\
Output & 0.4 & 0.5 & 5.2 & 1.3 & 14.7 \\
Input Use & 31.8 & 21.4 & 36.8 & 25.4 & 0.0 \\
Area & 0.0 & 0.0 & 0.0 & 0.0 & 2.1 \\
Historical Entitlements & 0.0 & 0.0 & 0.0 & 0.0 & 0.0 \\
Input Constraints & 0.0 & 0.0 & 0.0 & 0.0 & 0.0 \\
Overall Farm Income & 0.0 & 0.0 & 0.0 & 0.0 & \\
\hline \hline Source: OECD & & & & & \\
\hline
\end{tabular}

Source: OECD 
Figure 1: OECD Measures of Domestic Support

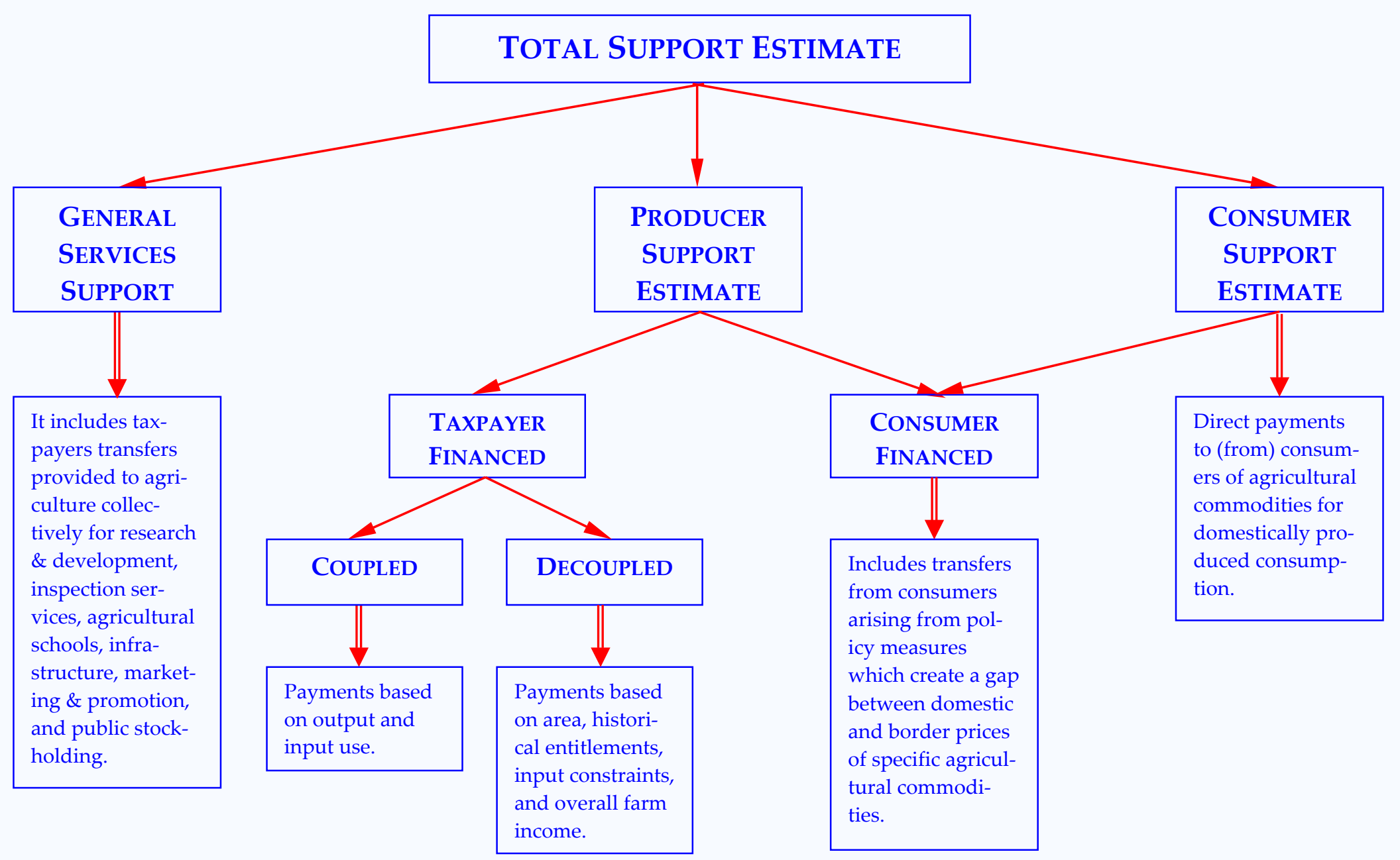

Notes: Export subsidies include both taxpayer- and consumer-financed transfers. Consumer-financed transfers include the PSE and CSE in exactly the same level except for opposite signs. Coupled and decoupled imply that support is not affected by production decisions but it can affect them. 


\section{Figure 2: WTO Measures of Domestic Support}

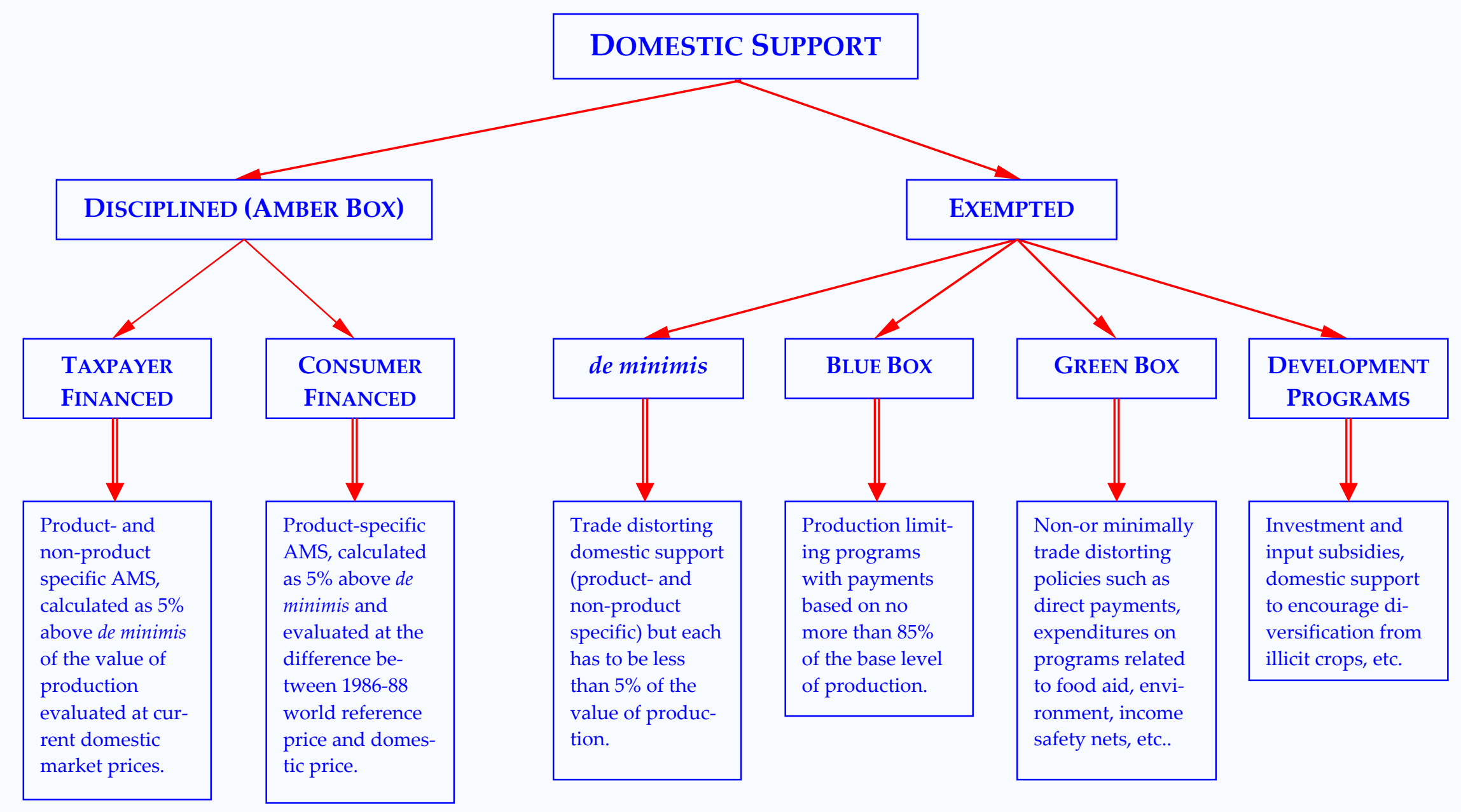

Notes: The 5\% above de minimis applies for the sum of taxpayer- and consumer-financed support. The de minimis exemption can include consumerfinanced support. 
Figure 3: Production Subsidy of a Large Exporter

A: Domestic Market

B: Rest of the World

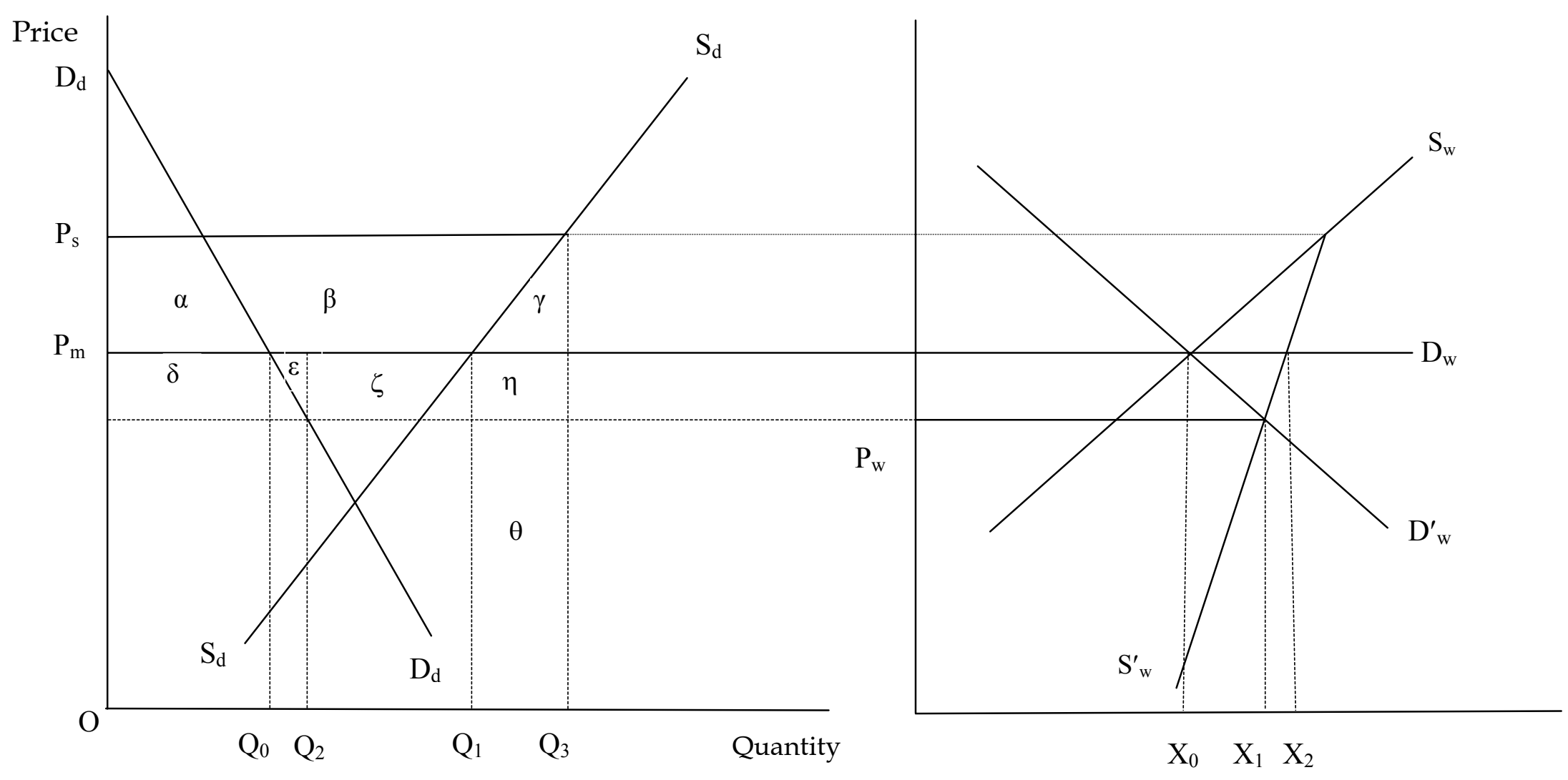


Figure 4: Import Tariff of a Large Importer

A: Domestic Market

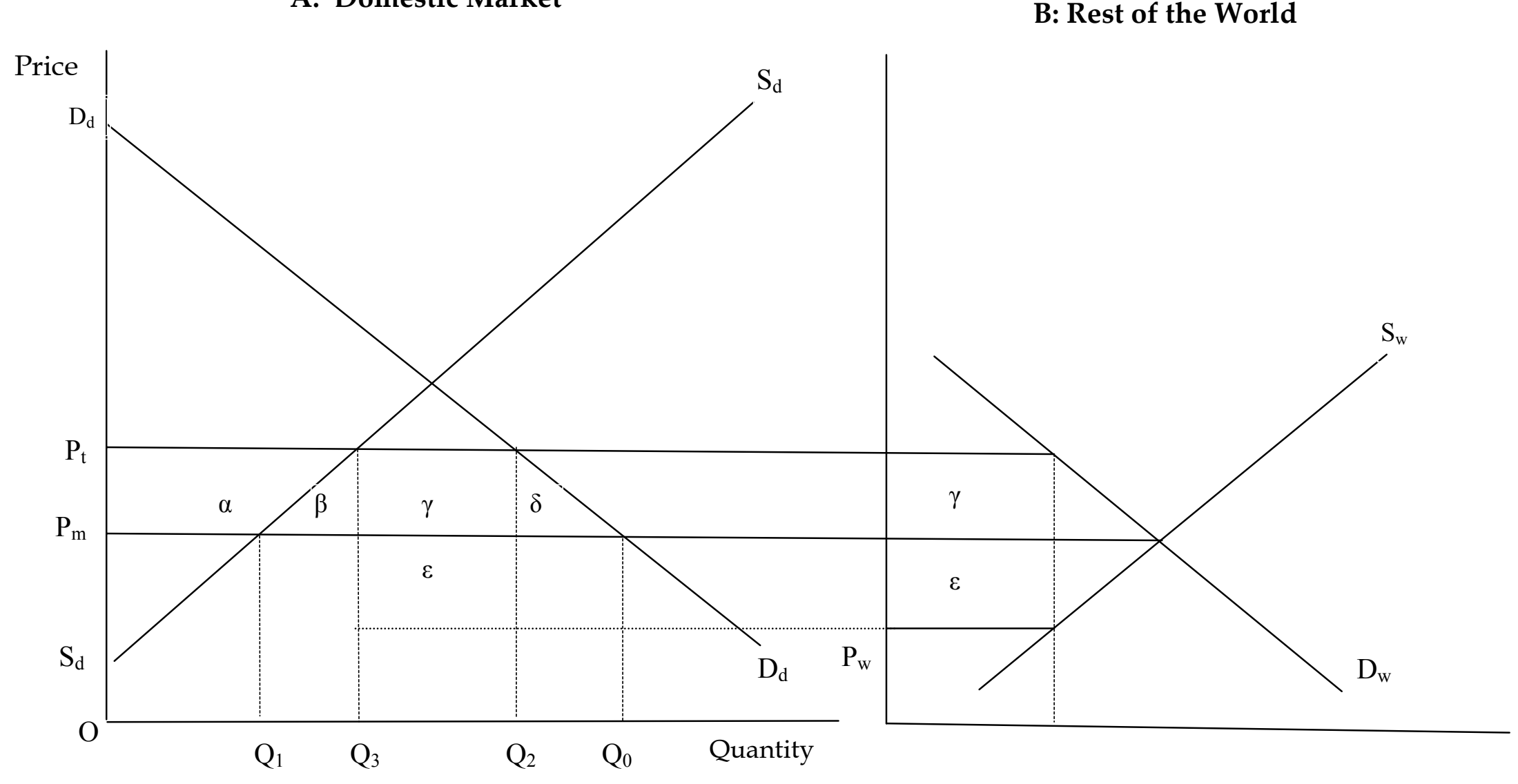




\section{REFERENCES}

Aksoy, Ataman M. (2004). “Global Agricultural Trade Policies." In Global Agricultural Trade and Developing Countries, ed. Ataman Aksoy and John Beghin. The World Bank, Washington DC.

Alston, Julian M. and Brian H. Hurd (1990). "Some Neglected Costs of Government Spending in Farm Programs." American Journal of Agricultural Economics, vol. 72, pp. 149-156.

Australian Bureau of Agricultural and Resource Economics (2002). "US and EU Agricultural Support: Who does it Benefit?" Current Issues, no. 2, October.

Baffes, John and Harry de Gorter (2004). "Experience with Decoupling Agricultural Support." In Global Agricultural Trade and Developing Countries, ed. Ataman Aksoy and John Beghin. The World Bank, Washington DC.

Baffes, John and Jacob Meerman (1998). "From Prices to Incomes: Agricultural Subsidization without Protection?" World Bank Research Observer, vol. 13(2), pp. 191-211.

Beard, Nick and Alan Swinbank (2001). "Decoupled Payments to Facilitate CAP Reforms." Food Policy, vol. 26, pp. 121-146.

Beghin, John C., Jean-Christophe Bureau, and Sung Joon Park (2003). "Food Security and Agricultural Protection in South Korea." American Journal of Agricultural Economics, vol. 85, pp. 618-632.

Black, John D. (1958). “The Extremities of Current Agricultural Policy Proposals.” Quarterly Journal of Economics, vol. 72(3), pp. 307-326.

Blair, Tony (2002). "Nigeria Needs to Succeed if Africa Is to Succeed." Speech given in Abuja, Nigeria, February 7. http://www.dfid.gov.uk/News/Speeches/files/sp pm 2002feb07.html (accessed April 28, 2003).

Brandow, George E. "A Modified Compensatory Price Program for Agriculture." Journal of Farm Economics, vol. 35, pp. 716-730.

Cahill, Sean, A. "Calculating the Rate of Decoupling for Crops under CAP/Oilseeds Reforms." Journal of Agricultural Economics, vol. 48, pp. 349-378.

Castañeda, Tarsicio (2004). "Compensation for Trade Reforms in Agriculture in Latin America and the Caribbean: Policy Options and Design and Implementation Issues." Mimeo, World Bank, Washington, D.C.

Chau, N. and Harry de Gorter (2002). "Disentangling the Consequences of Direct Payment Schemes in Agriculture on Fixed Costs, Exit Decisions and Output." Working Paper 2001-16, Department of Applied Economics and Management, Cornell University.

Christenson, Reo Millard (1959). The Brannan Plan-Farm Politics and Policy. University of Michigan Press, Ann Arbor, Michigan.

Chvosta, Jan, Walter N Thurman, Blake A. Brown, and Randal R. Rucker (2003). “The End 
of Supply Controls: The Economic Effects of Recent Change in Federal Peanut Policy." Paper presented at the Southern Agricultural Economics Association Annual Meeting, Mobile Alabama, February 1-5.

Cochrane, Willard W. and Mary E. Ryan (1976). American Farm Policy, 1948-1973. University of Minnesota Press, Minneapolis.

Corden. W. M. (1974). Trade Policy and Economic Welfare, Oxford University Press, Oxford, United Kingdom.

European Commission (2003). "Agricultural Reform Continued: Commission Proposes Sustainable Agricultural Model for Europe's Tobacco, Olive Oil and Cotton Sectors." Brussels.

Feenstra, Robert C. (1986). The Theory of Commercial Policy: Essays in International Economic Theory. The MIT Press, Cambridge Massachusetts.

Feldstein, Martin (1999). "Tax Avoidance and the Deadweight Loss of the Income Tax." Review of Economics and Statistics, vol. 81, pp. 674-680.

Peter Finkle and Duncan Cameron. Decoupling: The Concept and its Future in Canada (editors). Ottawa, Canada.

FitzGerald, Niall (2002). “Annual City Food Lecture.” Speech given in London, January 16. http://www.unilever.com/news/speeches/englishspeeches 3471.asp (accessed April 28, 2003).

Foreign Policy (2003). "Ranking the Rich." May/June, no. 136, pp. 56-66.

Gardner, Bruce (2002). “U.S. Commodity Policies and Land Prices.” Working paper no. 0202, Department of Agricultural and Resource Economics, University of Maryland, College Park, MD.

Gardner, Bruce (1983). "Efficient Redistribution through Commodity Markets." American Journal of Agricultural Economics, vol. 65, pp. 225-234.

Gilson, Clayton, J. (1988). "Early Experiences with the Coupling and Decoupling of Agricultural Price Supports and Farm Commodities." In Decoupling: The Concept and its Future in Canada, ed. Peter Finkle and Duncan Cameron. Ottawa, Canada.

Goodwin, Barry K. and Ashok K. Mishra (2002). "Are 'Decoupled' Farm Program Payments Really Decoupled? An Empirical Evaluation." Mimeo, The Ohio State University. http://departments.agri.huji.ac.il/economics/kenes-goodwin2.pdf

Goodwin, Barry K, Ashok K. Mishra, and Francois N. Ortalo-Magnè (2003). "What's Wrong with Our Models of Agricultural Land Values?" American journal of Agricultural Economics, 85(3), pp. 744-752.

Hennessy, David A. (1998). "The Production Effects of Agricultural Income Support Policies under Uncertainty." American Journal of Agricultural Economics, 80, pp. 46-57.

Huffaker, Ray G. and Delworth B. Gardner (1986). "The Distribution of Economic Rents Arising from Subsidized Water when Land is Leased." American Journal of Agricultural 
Economics, 68, pp. 306-312.

Jansen, H. Tarp, Sherman Robinson, and Finn Tarp (2002). "General Equilibrium Measures of Agricultural Policy Bias in Fifteen Developing Countries." TMD Discussion Paper 105. International Food Policy Research Institute, Washington, D.C.

Johnson, James D. and Sara D. Short (1983). “Commodity Programs: Who Has Received the Benefit?" American Journal of Agricultural Economics, vol. 65, pp. 523-544.

Klein, K. K. and W. A. Kerr (1995). "The Crow rate Issue: A Retrospective on the Contributions of the Agricultural Economics Profession in Canada." Canadian Journal of Agricultural Economics, 44, pp. 1-18.

Krueger, Anne O. (1974). “The Political Economy of the Rent-Seeking Society.” American Economic Review, 64(3), pp. 291-303.

Lence, Sergio H. and Ashok K. Mishra (2003). "The Impacts of Different Farm Programs on Cash Rents." American Journal of Agricultural Economics, 85(3), pp. 753-761.

Little, Jonathan, Thomas Knapp, Miguel Sottomayor, and Alan Swinbank (2004). “Compensation Proposals for EU Farm Policy Reform." In A Bond Scheme for Common Agricultural Policy, ed. Alan Swinbank and Richard Tranter, CABI Publishing, Cambridge, MA.

Marsh J. S. (Rapporteur) (1970). A New Agricultural Policy for Europe. Proposals submitted by the Agricultural Study Group of the Federal Trust. Federal Trust for Education and Research, London.

Moschini, Giancarlo and Paolo Sckokai (1994). "Efficiency of Decoupled Programs Under Distortionary Taxation." American Journal of Agricultural Economics, 73, pp. 262-370.

Munk, Knud Jorgen (1989). "Price Support to the EC Agricultural Sector: An Optimal Policy?" Oxford Review of Economic Policy, 5(2), pp. 76-89.

Nash, Eric Francis (1961). "Agriculture." In Agenda For A Free Society: Essays on Hayek's 'The Constitution of Liberty', ed. Arthur Selton. The Institute of Economic Affairs, London.

Nash, Eric Francis and E. A. Attwood (1961). The Agricultural Policies of Britain and Denmark: A Study of Reciprocal Trade. Land Books, London.

Nicholls William H. and D. Gale Johnson (1946). “The Farm Price Policy Awards, 1945: A Topical Digest of the Winning Essays." Journal of Farm Economics, 27(1), pp. 267-283.

Orden, David and Kathleen Mullen (2004) "Producer Support Estimates (PSEs) for Agriculture in the Developing Countries: Illustrations from China and India" Markets, Trade and Institutions Division, IFPRI, Washington, D.C.

Orden, David, Robert Paarlberg, and Terry Roe (1999). Policy Reform in American Agriculture: Analysis and Prognosis, The University of Chicago Press, Chicago.

Organization of Economic Cooperation and Development (2004). "Risk of PSE Crop Measures" AGR/CA/APM(2002)13, Paris 
(2003a). "Effects of Quantitative Constraints on the degree of decoupling of crop support measures" AGR/CA/APM(2002)12, Paris.

(2003b). "Risk related non-price effects of the CAP Arable Crop Regime: Results from an FADN Sample" AGR/CA/APM(2002)14.

(2001). The Incidence and Income Transfer Efficiency of Farm Support Measures. AGR/CA/APM(2001)24, Paris.

(2000a). Decoupling: A Conceptual Overview. COM/AGR/APM/TD/WP(2000)14, Paris.

(2000b). Methodology for the Measurement of Support and Use in Policy Evaluation, Paris.

Parry, Ian W. H. (1997). "Agricultural Policies in the Presence of Distorting Taxes." Discussion Paper 98-05, Resources for the Future. Washington, DC.

Phipps, Tim (1982). Farm Policies and the Rate of Return on Investment in Agriculture, Occasional Paper, American Enterprise Institute, Washington, D.C.

Phipps, Tim (2003). “Discussion of Agricultural Land Values, Government Payments, and Production." American Journal of Agricultural Economics, vol. 85(3), pp. 770-771.

Quiroz, Jorge and Luis Opazo (2000). “The Krueger-Schiff-Valdés Study 10 Years Later: A Latin American Perspective." Economic Development and Cultural Change, 49(1), pp. 18196.

Roe, Terri and Agapi Somwaru, and Xinshen Diao (2004). "Decoupled Payments: A Dynamic, Economywide Perspective." In Decoupled Payments in a Changing Policy Setting, ed. Mary Burfisher and Jeffrey Hopkins. US Department of Agriculture, Agricultural Economic Report No. 838.

Roberts, Ivan (2003). Three Pillars of Agricultural Support and their Impact on WTO Reforms. ABARE eReport, 03.5. Commonwealth of Australia.

Roberts, Michael J. Barrett Kirwan, and Jeffrey Hopkins (2003). “The Incidence of Government Program Payments on Agricultural Land Rents: The Challenges of Identification." American Journal of Agricultural Economics, 85(3), pp. 762-769.

Sadoulet, Elisabeth, Alain de Janvry, and Benjamin Davis (2001). "Cash Transfers with Income Multipliers: PROCAMPO in Mexico." World Development, 29, pp. 1043-1056.

Spriggs, John and Dale Sigurdson (1988). "The Economics of Decoupling and Targeting Canada's Grain and Livestock Stabilization Programs." In Decoupling: The Concept and its Future in Canada, ed. Peter Finkle and Duncan Cameron. Ottawa, Canada.

Swerling, Boris G. (1959). "Income Protection for Farmers: A Possible Approach.” Journal of Political Economy, 64(2), pp. 173-186.

Swinbank, Alan (2004). "Decoupled Payments and a Triad of Policy Objectives: Compensation, Farm Income Support and Multifunctionality." In A Bond Scheme for Common Agricultural Policy, ed. Alan Swinbank and Richard Tranter. CABI Publishing, Cam- 
bridge, MA.

Swinbank, Alan and Richard Tranter (2004). In A Bond Scheme for Common Agricultural Policy. CABI Publishing, Cambridge, MA.

Swinbank, Alan and Stefan Tangermann (2001). "The Future of Direct Payments under the CAP: A Proposal" EuroChoices, pp. 28-35.

Tangermann, Stefan (1991). "A Bond Scheme for Supporting Farm Incomes." In The Changing Role of the Common Agricultural Policy: The Future of Farming in Europe, ed. J. S.

Marsh et al. Belhaven, London.

Traill, Bruce W. (1982). “The Effect of Price Support Policies on Agricultural Investment, Employment, Farm Incomes, and Land Values in the U.K." Journal of Agricultural Economics, 33, pp. 369-385.

Turvey, Calum G. (2003). "Agricultural Land Values, Government Payments, and Production: Discussion." American journal of Agricultural Economics, 85(3), pp. 772-773.

United Nations (2003). Human Development Report-Millennium Development Goals: A Compact Among Nations to End Human Poverty. Oxford University Press, New York.

United States Department of Agriculture (2004). “Tobacco Transition Payment Program." Farm Service Agency, October 22, Washington, DC.

(2003). “Decoupled Payments: Household Income Transfers in Contemporary US Agriculture." Economic Research Service, Agricultural Economic report no. 822. Washington, DC.

Uri, Pierre (1970). A Future for European Agriculture. The Atlantic Institute, Paris.

Van Donkersgoed (1988). "Decoupling: A Family Farm and Stewardship Approach." In Decoupling: The Concept and its Future in Canada, ed. Peter Finkle and Duncan Cameron. Ottawa, Canada.

Van Riemsdijk, J. (1973). "A System of Direct Compensation Payments to Farmers as a Means of Reconciling Short-Run to Long-Run Interests." European Review of Agricultural Economics, 1, pp. 161-189.

Vatn, Arild (2002). “Multifunctional Agriculture: Some Consequences for International Trade Regimes." European Review of Agricultural Economics, 29, pp. 309-327.

Vercammen, James (2003). “A Stochastic Dynamic Programming Model of Direct Subsidy Payments and Agricultural Investment." Paper presented at the joint Annual Meetings of the American Agricultural Economics Association and the Canadian Agricultural Economics Society, Montreal, Canada, July 27-30.

Wallace, T. D. (1962). "Measures of Social Costs of Agricultural Programs." Journal of Farm Economics, 44, pp. 580-594.

Winters, L. Alan (1989-90). “The So-Called 'Non-Economic' Objectives of Agricultural Support." OECD Economic Studies, 13, pp. 238-266. 
World Bank (2004a). Global Economic Prospects and the Developing Countries: Realizing the Development Promise of the Doha Agenda. Washington, D.C.

(2004b). "Turkey: A Review of the Impact of the Reform of Agricultural Sector Liberalization." Environmentally and Socially Sustainable Development Sector Unit, Europe and Central Asia Region. Washington, D.C. (2003). Global Economic Prospects and the Developing Countries. Washington, D.C. (2001). “Turkey-Agricultural Reform Implementation Project." Project Appraisal Document, Turkey Country Unit, Europe and Central Asia Region. Washington, DC. (1996). "Mexico-Agricultural Sector Adjustment Projects I and II." Project Performance Audit Report, Operations Evaluation Department. Washington, DC. (1994). "Mexico-Agricultural Sector Memorandum." Green Cover Report 13425ME, Natural Resources and Rural Poverty Division, Country Department II, Latin American and the Caribbean Regional Office. Washington, DC.

World Trade Organization (2004). United States-Subsidies on Upland Cotton: Report of the Panel. WT/DS/267. Geneva, September 8. (2003). Poverty Reduction: Sectoral Initiative in Favour of Cotton-A Joint Proposal by Benin, Burkina Faso, Chad, and Mali. TN/AG/GEN/4. Geneva, May 16. (2002). United States - Subsidies on Upland Cotton: Request for Consultations by Brazil. WT/DS267/1. Geneva, October 3. 